\title{
The Merchandising Right: Fragile Theory or Fait Accompli? ${ }^{1}$
}

\author{
Stacey L. $\operatorname{Dogan}^{2}$ \& Mark A. Lemley ${ }^{3}$
}

Trademark merchandising is big business. One marketing consultant estimated the global market for licensing and marketing sports-related merchandise at \$17 billion in 2001. ${ }^{4}$ The college-logo retail market was estimated at \$3 billion in 2003. ${ }^{5}$ The 2002 Salt Lake Olympics generated \$500 million in gross sales, and \$34 million in licensing revenues, from sale of "Olympics” attire. ${ }^{6}$ Even municipal police departments want a piece of the action, applying to register their names as trademarks ${ }^{7}$ and demanding

1 (C) 2004 Stacey L. Dogan \& Mark A. Lemley.

2 Associate Professor of Law, Northeastern University School of Law.

3 William H. Neukom Professor of Law, Stanford Law School; Director, Stanford Program in Law, Science and Technology; of counsel, Keker \& Van Nest LLP.

Thanks to Rob Denicola, Paul Goldstein and Thomas McCarthy for comments on the project or an earlier draft.

$4 \quad$ Ardi Kolah, Maximising Revenue from Licensing and Merchandising, avail. at http://www.sportbusinessassociates.com/sports_reports/Licensing\%20and\%20Merchandi sing\%20brochure.pdf (last visited July 26, 2004) (also reporting that \$200 million of NFL merchandise was sold in 2001, and that Manchester United earned \$36 million from global merchandising fees).

5 See Jeffrey Zaslow, Sports Fans Snap Up Souvenirs of Winners Beating Losers: Mascots Boiled or Grilled?, WALL ST. J., Nov. 12, 2003, at A1. Another report recently estimated that universities collect over $\$ 2.5$ billion annually in revenues from officially licensed products. Glenn Bacal \& Sean Johnson, Collegiate Trademark Licensing: The Basic Rules of the Game, published online by Office of General Counsel, Arizona State University, at http://www.asu.edu/counsel/brief/trademark.html\#N_2_ (last visited July 26, 2004). See C. Knox Withers, Sine Qua Non: Trademark Infringement, Likelihood of Confusion, and the Business of Collegiate Licensing, 11 J. Intell. Prop. L. 421, 422 (2004) (suggesting $\$ 2.7$ billion in collegiate revenue).

${ }^{6}$ International Olympic Committee, Salt Lake 2002 Licensing, in Marketing Matters: The Olympic Marketing Newsletter, p. 4, avail. at http://multimedia.olympic.org/pdf/en_report_456.pdf

7 See, e.g., United States Patent and Trademark Office, Trademark Application Serial Number 75,791,989 (filed Sept. 2, 1999) (application to register “LAPD” for use on 
royalties from television programs designed to evoke their image. ${ }^{8}$ Want to wear a hat showing your support for your college or favorite baseball team? Want to wear a T-shirt emblazoned with the word "Barbie" or the "Harley-Davidson” logo? You may have no choice but to get an officially licensed piece of gear, at least if trademark owners have their way. ${ }^{9}$

clothing and children's clothing); United States Patent and Trademark Office, Trademark Application Serial Number 76,342,567 (filed Nov. 28, 2001) (opposition pending as of July 27, 2004) (application to register "NYPD" for use on clothing, housewares and glasses, furniture, jewelry, keyrings, mousepads, and a host of other merchandise).

8 The New York and Los Angeles police departments have reportedly begun to demand royalties for the use of the NYPD and LAPD names. According to a New York police department spokesperson, “'[w]e're concerned about the marketing logo, what people do with it, and what it indicates. If they do [use it] they either enter into an agreement and, if they don't, we sue.”' Bridget Byrne, Real Cops on TV Beat, Eonline, Aug. 5, 2002, avail. at http://www.eonline.com/News/Items/0,1,10347,00.html (last visited July 27, 2004). See also Dana Calvo \& Richard Winton, Impersonating an Officer Could Be Costly in Los Angeles; Unlike in the days of 'Dragnet,' two new shows may be charged licensing fees to use the LAPD name, L.A. Times (Calendar), July 31, 2002, at 1 ("In a break with tradition, City Atty. Rocky Delgadillo has asked the networks that air two new L.A.based police TV shows to pay licensing fees or risk legal action, saying the city in the past has 'basically been lazy about its intellectual property' rights under trademark law.").

9 Trademark holders have not limited their zeal to merchandising cases, but behave generally as though their rights to their brand names and logos are all but absolute. Some trademark holders have attempted to sue anyone who makes use of the term, even in contexts like parody or criticism that pose no threat of consumer confusion, the traditional touchstone for trademark infringement claims. Trademark laws have been used to preclude artists from painting in the same style as another, Romm Art Creations Ltd. v. Simcha Int'l 786 F. Supp. 1126 (E.D.N.Y. 1992); to prevent an author from using the term "Godzilla" in the title of his book about Godzilla, notwithstanding prominent disclaimers, see Toho Co. v. William Morrow \& Co., 46 U.S.P.Q.2d 1801 (C.D. Cal. 1998); to prevent a comic book from featuring a character known as Hell's Angel, see White v. Samsung Elecs. Am., 989 F.2d 1512, 1513 n.6 (9th Cir. 1993) (detailing the trademark suit and the settlement); to prevent a satirical political advertisement from using the "Michelob" trademark to help make its point, see Anheuser-Busch v. Balducci Publications, 28 F.3d 769 (8th Cir. 1994); to prevent a tractor manufacturer from making fun of its competitor's logo in an advertisement, see Deere \& Co. v. MTD Prods., 41 F.3d 39, 44-45 (2d Cir. 1994); to prevent a movie about a Minnesota beauty pageant from using the title "Dairy Queens," see American Dairy Queen Corp. v. New Line Prods., 35 F. Supp. 2d 727 (D. Minn. 1998); to prevent a political satire of the O.J. Simpson case 
With this much money at stake, it's no surprise that trademark holders demand royalties for use of "their" marks on shirts, keychains, jewelry, and related consumer products. After all, the value of these products comes largely from the allure of the trademarks, and it seems only fair to reward the party that created that value...doesn't it?

It turns out that the answer is more complicated than this intuitive account would predict. Trademark law historically has existed primarily to protect against the consumer deception that occurs when one party attempts to pass off its products as those of another. ${ }^{10}$ From an economic and policy perspective, it is by no means obvious that

called “The Cat NOT in the Hat!”, see Dr. Seuss Enters. v. Penguin Books USA, 109 F.3d 1394, 1397 (9th Cir. 1997); to prevent individuals from setting up web pages critical of a company or product, see Ohio Art Co. v. Watts, No. 98 CV 7338, slip op. at 4 (N.D. Ohio June 23, 1998); BellSouth Corp. v. Internet Classified of Ohio, No. 1:96-CV-0769CC, slip op. at 29-30 (N.D. Ga. Nov. 12, 1997); and to prevent a theme bar from calling itself “The Velvet Elvis," see Elvis Presley Enters. v. Capece, 141 F.3d 188 (5th Cir. 1998). In still other cases, plaintiffs have tried without success to prevent a variety of artists, authors, political groups, news agencies, and others from using their trademarks. See, e.g., Fox News Network v. Penguin Group, 2003 WL 23281520 (S.D.N.Y. Aug. 20, 2003) (attempt to prevent political humor book from using the phrase "fair and balanced" in its title); Mastercard Int'l v. Nader 2000 Primary Committee, 70 U.S.P.Q.2d 1046 (S.D.N.Y. 2004) (attempt to enjoin political speech in a presidential campaign that parodied a trademark); American Family Life Ins. Co. v. Hagan, 266 F. Supp. 2d 682 (N.D. Ohio 2002) (same); New Kids on the Block v. News Am. Publ'g, 971 F.2d 302 (9th Cir. 1992) (attempt to prevent a newspaper from referring to the band "New Kids on the Block” in a for-profit telephone poll); Lyons Partnership v. Giannoulas, 14 F. Supp. 2d 947 (N.D. Tex. 1998) (attempt to prohibit a comedy routine by the San Diego Chicken in which it beat up a Barney character); Lucasfilm Ltd. v. High Frontier, 622 F. Supp. 931 (D.D.C. 1985) (attempt to prohibit the use of the term "Star Wars" to describe the Reagan Administration's Strategic Defense Initiative); Girl Scouts v. Personality Posters Mfg., 304 F. Supp. 1228 (S.D.N.Y. 1969) (attempt to enjoin printing, distribution and sale of a poster showing a pregnant girl in a Girl Scout uniform with the caption "Be Prepared”). Those suits have been discussed in great deal elsewhere, and they will not concern us further here. See, e.g., Mark A. Lemley, The Modern Lanham Act and the Death of Common Sense, 108 Yale L.J. 1687 (1999); Jessica Litman, Breakfast With Batman: The Public Interest in the Advertising Age, 108 Yale L.J. 1717 (1999); Glynn S. Lunney, Jr., Trademark Monopolies, 48 Emory L.J. 367 (1999).

10 The law also protects against confusion as to affiliation or sponsorship, but there, too, the cause of action turns on the existence of confusion in the marketplace. See infra 
trademark holders should have exclusive rights over the sale of products that use marks for their ornamental or "intrinsic" value, rather than as indicators of source or official sponsorship. ${ }^{11}$ Trademark law seeks to promote, rather than hinder, truthful competition in markets for products sought by consumers; if a trademark is the product, then giving one party exclusive rights over it runs in tension with the law's pro-competitive goals, frequently without any deception-related justification. ${ }^{12}$ On the other hand, there may be circumstances in which consumers expect that trademark holders sponsored or produced products bearing their mark, in which case use of the mark by others - even as a part of a product - might result in genuine confusion. ${ }^{13}$ At the very least, the fact that the notes _ _-_ and accompanying text; J. Thomas McCarthy, McCarthy on Trademarks, $\S 18.39-18.40$ (describing distinction between "source theory" of protection and "quality theory" of protection). Federal dilution law, which protects against the "whittling away" or tarnishment of a famous trademark's distinctiveness, will rarely come into play in merchandising cases. See infra notes _ _ _ and accompanying text.

${ }^{11}$ See International Order of Job’s Daughters v. Lindeburg \& Co., 633 F.2d 912, 918 (9 $9^{\text {th }}$ Cir. 1980), cert. denied, 452 U.S. 941 (1981) ("It is not uncommon for a name or emblem that serves in one context as a collective mark or trademark also to be merchandised for its own intrinsic utility to consumers.”). Of course, trademarks sometimes serve a dual function, as source identifier and as an integral aesthetic feature of the product. In these cases, the interests of truthfulness and robust competition run into tension with one another, and the solution becomes more challenging. We discuss such cases infra notes _-_ and accompanying text.

${ }^{12}$ Imagine, for example, that I am a Dallas Cowboys fan who wants to wear a Cowboys tshirt to show my support for the team. In that case, the trademark is an essential part of the product I'm seeking - I am not looking to buy just any t-shirt, but a t-shirt with COWBOYS as its defining feature. And I may or may not assume (or care) that the Cowboys themselves had any relationship to the sale or manufacture of the shirt. See Robert C. Denicola, Institutional Publicity Rights: An Analysis of the Merchandising of Famous Trade Symbols, 62 N.C. L. Rev. 603, 604 (1984) (noting that items with logos sell despite their high price relative to other items of similar quality). See generally Alex Kozinski, Trademarks Unplugged, 68 N.Y.U. L. Rev. 960, 961 (1993) (discussing the "growing tendency to use trademarks not just to identify products but also to enhance or adorn them, even to create new commodities altogether").

${ }^{13}$ See, e.g., National Football League Properties, Inc. v. New Jersey Giants, Inc., 637 F. Supp. 507, 515 (D.N.J. 1986) (survey showed that up to 67\% of football fans were 
trademark constitutes part of the product, rather than purely an indication of source, complicates the analysis, raising a tension between the dual goals of trademark law. ${ }^{14}$

Given these complexities, together with the economic interests at stake, one might expect that the law and practice of merchandising rights would be well-settled and reflect a considered balancing of the interests of trademark holders and their competitors. In reality, however, much of the multi-billion dollar industry of merchandise licensing has grown around a handful of cases from the 1970s and 1980s that established merchandising rights with little regard for the competing legal or policy concerns at stake. Those cases are far from settled law - indeed, at least as many decisions decline to give trademark owners the right to control sales of their trademarks as products. We think it is high time to revisit that case law and to reconsider the theoretical justifications for a merchandising right.

That review provides little support for trademark owners’ assumptions about merchandising. Doctrinally, the most broad-reaching merchandising cases - which presumed infringement based on the public recognition of the mark as a trademark ${ }^{15}$ were simply wrong in their analysis of trademark infringement and have been specifically

confused as to the NFL's sponsorship of GIANTS merchandise); $c f$. National Football League Properties, Inc. v. Wichita Falls Sportswear, Inc., 532 F. Supp. 651 (W.D. Wash. 1982) (up to $53.6 \%$ of consumers who saw defendant's replicas of NFL jerseys believed that the use required permission from the NFL).

${ }^{14}$ See Denicola, supra note _, at 611; Bone, supra note _ , [draft at 67-68].

15 "The certain knowledge of the buyer that the source and origin of the trademark symbols were in the plaintiffs satisfies the requirements of the act.” Boston Professional Hockey Ass'n, Inc. v. Dallas Cap \& Emblem Mfg., Inc., 510 F.2d 1004, 1012 (5 ${ }^{\text {th }}$ Cir.) (emphasis added), cert. denied, 423 U.S. 868 (1975). 
rejected by subsequent decisions. ${ }^{16}$ Philosophically, even a merchandising right that hinges on likelihood of confusion raises competition-related concerns that should affect courts' analysis of both the merits and appropriate remedies in merchandising cases. Perhaps most importantly, recent Supreme Court case law suggests that, if it had the opportunity to evaluate the merchandising theory (something it has never done), the Court would deny the existence of such a right. Further, the Court would be right to do so. When a trademark is sold, not as a source indicator, but as a desirable feature of a product, competition suffers - and consumers pay - if other sellers are shut out of the market for that feature. ${ }^{17}$

In Part I, we discuss the historic background and general principles of trademark law, and trace the growth of the merchandising right theory from the 1970s through the present, when the assumption of a merchandising right has become a standard part of business practice. In Part II, we explore the legal and theoretical viability of such a

${ }^{16}$ See infra notes _____ and accompanying text.

${ }^{17}$ Robert Bone has aptly pointed out that product markets are hard to define in these cases, and that competition won't suffer if the trademark is competing as but one of many competing ornamental features on the relevant product. But this seems unlikely in the merchandising cases. A Dallas Cowboys fan won't be satisfied with a Washington Redskins T-shirt instead. If there is an identifiable product market, in the sense that the trademark holder can command an above-market price because of the feature, the Supreme Court has suggested that some remedy short of an injunction - such as a disclaimer - is most appropriate to alleviate any confusion. See, e.g., Kellogg Co. v. National Biscuit Co., 305 U.S. 111, 122 (1938); Bonito Boats, Inc. v. Thunder Craft Boats, Inc., 489 U.S. 141, 154 (1989); cf. Sears, Roebuck \& Co. v. Stiffel Co., ("Doubtless a state may, in appropriate circumstances, require that goods, whether patented or unpatented, be labeled or that other precautionary steps be taken to prevent customers from being misled as to the source, ... [b]ut because of the federal patent laws a State may not ... prohibit the copying of the article itself or award damages for such copying.”); Traffix Devices, Inc. v. Marketing Displays, Inc., 532 U.S. 23, 34-35 (2001) (asserting categorically that trademark protection may not extend to functional features even if consumers associate them with a particular source). Even the courts that find clear evidence of trademark confusion have not engaged in this second level of analysis. 
claim. We find the basis for an absolute merchandising right quite weak. The justifications offered for a merchandising right tend to be circular, and to assume that because it is possible to capture value by using a brand, the trademark owner must own the right to control that value. Making this assumption relegates competition and consumer search costs to secondary status. While the question is not free from doubt, and there are arguable justifications for limited protection in certain circumstances, the concerns we discuss in this section do not justify a general merchandising right. Finally, Part III considers how the Supreme Court would treat the merchandising theory if it were presented with such a case. Recent Supreme Court trademark cases suggest that the Court is quite concerned to protect competition against expansive readings of the trademark right, an approach that suggests that it would not look kindly on the merchandising theory.

\section{Origins of the Merchandising Right: From Trademark as Brand to Trademark as Product}

\section{A. Trademarks, Confusion, and Competition}

“Trademarks have existed for almost as long as trade itself." ${ }^{18}$ From the earliest days in which merchants made and sold goods for consumption by others, sellers have used names and other symbols to indicate the source of their wares. ${ }^{19}$ These "marks"

${ }^{18}$ Merges et al., supra note _, at 529; see also Frank Schechter, The Historical Foundations of the Law Relating to Trademarks (1925) (tracing history of trademark law to medieval times).

${ }^{19}$ Merges et al., supra note _, at 529. We refer to "trademarks" in this paper, but the 
serve an important economic function: they enable sellers to develop reputations for quality, and assure customers that products sold under the seller's brand will live up to that reputation. Trademarks, in other words, provide convenient, truthful product information in easily accessible form. ${ }^{20}$

To fulfill their informational objectives, trademarks require some form of legal protection. A brand-based assurance of quality would mean nothing if imitators could apply it to their own products and pass them off as having come from the trademark holder. The result would be higher search costs for consumers and a disincentive to firms to invest in goodwill and quality products and services. Trademark law evolved specifically to avoid this result. Doctrinally, trademark law prevents interlopers from appropriating trademark holders' goodwill by using their marks in a way that suggests some association, affiliation, or sponsorship between the parties or their products. Economically, trademark law reduces consumer search costs and facilitates investment in goodwill by protecting the accuracy of trademark-related investments in advertising and product quality. ${ }^{21}$

law and policies that we discuss apply equally to service marks, which are used to distinguish the services of one party from those of another. See 45 U.S.C. § 1127.

${ }^{20}$ For a more expansive discussion of the economics of trademark law, see Stacey L. Dogan \& Mark A. Lemley, Trademarks and Consumer Search Costs on the Internet, 43 Hous. L. Rev. _ (forthcoming 2004); see also See William Landes \& Richard Posner, The Economic Structure of Intellectual Property Law 167 (2003); William Landes \& Richard Posner, Trademark Law: An Economic Perspective, 30 J. L. \& Econ. 265, 26870 (1987); Mark A. Lemley, The Modern Lanham Act and the Death of Common Sense, 108 Yale L.J. 1687, 1690-93 (1999) (describing economic justifications for trademarks and advertising); Robert G. Bone, Enforcement Costs and Trademark Puzzles, _ VA. L. REV. _ (forthcoming 2004) (draft at 9-12). The informational function of trademarks is particularly important for products whose salient characteristics are not evident upon inspection. See, e.g., Bone, supra, at [draft at 11-12].

${ }^{21}$ Not all commentators view the by-products of trademark law as desirable. In 
While the reduction of consumer search costs and the encouragement of goodwill investment represent critical intermediate objectives of the trademark system, neither of these goals is an end in and of itself. The law reduces consumer search costs in order to facilitate the functioning of a competitive marketplace. Informed consumers will make better-informed purchases, which will increase their overall utility and push producers to develop better quality products. ${ }^{22}$ Trademark law, then, aims to promote more competitive markets by improving the quality of information in those markets. ${ }^{23}$

The primacy of competition in trademark law stands in stark contrast with other areas of intellectual property law, which insulate creators from competition in order to encourage future acts of creation. ${ }^{24}$ Copyright and patent law offer creators exclusive

particular, an influential scholarly movement in the early 1900s criticized trademark law for its tendency to encourage wasteful expenditures on advertisements that resulted in product differentiation and noncompetitive pricing. See, e.g., Ralph S. Brown, Jr., Advertising and the Public Interest: Legal Protection of Trade Symbols, 57 Yale L.J.1165, 1169 (1948) ("Considering the economic welfare of the community as a whole, to use up part of the national product persuading people to buy product A rather than product B appears to be a waste of resources.”); see also Lunney, Trademark Monopolies, supra note

${ }^{22}$ Indeed, classical economics requires fully informed buyers and sellers as a condition for a perfectly competitive economy. See Maureen A. O'Rourke, Shaping Competition on the Internet: Who Owns Product and Pricing Information?, 53 Vand. L. Rev. 1965, 1968 (2000) (describing conditions for perfectly competitive market).

${ }^{23}$ Cf. Landscape Forms, Inc. v. Columbia Cascade Co., 113 F.3d 373, 379 (2d Cir. 1997) ("the Lanham Act must be construed in light of a strong federal policy in favor of vigorously competitive markets, which is exemplified by the Sherman Act and other antitrust laws").

24 See 17 U.S.C. § 106 (setting forth exclusive rights of copyright holders); 35 U.S.C. $\S 271$ (defining exclusive rights of patent holders). The exclusive rights offered by copyright and patent law do not necessarily give the rights-holder economic power in any relevant market, because in most cases, the creator's work faces competition from other products that serve a similar market demand. See, e.g., 1 Herbert Hovenkamp et al., IP and Antitrust $\S 4.2$ (2004 ed.) (pointing out that most patents and copyrights do not confer market power in a relevant market). Nonetheless, the laws give rights-holders the 
economic rights to cure the presumed market failure that would result if copiers could replicate expressive works and inventions without incurring the costs of their development. $^{25}$ As such, these regimes were created specifically to encourage the creation of intrinsically valuable products. Trademark law quite consciously does not serve this goal; both its philosophy and its structure eschew the notion that trademark rights should serve as either an inducement or a reward for the creation of product features that have inherent - as opposed to source-identifying - value. ${ }^{26}$

While the reach of trademark law has expanded over the centuries, the law has

ability to exclude others from copying product features that consumers may demand for their inherent qualities. And if they succeed in creating incentives, it is because they permit creators to price in excess of marginal cost.

${ }^{25}$ See Wendy J. Gordon, Asymmetric Market Failure and Prisoner's Dilemma in Intellectual Property, 17 U. Dayton L. Rev. 853 (1992).

${ }^{26}$ See, e.g., Dastar Corp. v. Twentieth Century Fox Film Corp., 539 U.S. 23, 34 (2003) (“'The Lanham Act,' we have said, 'does not exist to reward manufacturers for their innovation in creating a particular device; that is the purpose of the patent law and its period of exclusivity.”) (quoting TrafFix Devices, Inc. v. Marketing Displays, Inc., 532 U.S. 23, 34 (2001)); see also 17 U.S.C. § 1052(e)(5) (prohibiting the registration of any trademark that "comprises any matter that, as a whole, is functional"); Qualitex Co. v. Jacobson Prods Co., Inc., 514 U.S. 159, 164 (1995) ("It is the province of patent law, not trademark law, to encourage invention by granting inventors a monopoly over new product designs or functions for a limited time, ... after which competitors are free to use the innovation.”). Of course, distinguishing between the inherent and source-identifying functions of a particular product feature can be daunting. See, e.g., Bone, supra note at [draft at 80-81] (distinguishing between consumption value and source-identification function of particular product features).

The structure of trademark law is also ill-suited to protection of appealing product features. Unlike copyright and patent rights, which expire after a defined term, trademark law provides protection for as long as the mark serves as a source-indicator. As a result, when trademark law extends to product features that have intrinsic value, the trademark holder can obtain a potentially perpetual monopoly over those product features. Cf. Qualitex, 514 U.S. at 164-65 ("If a product's functional features could be used as trademarks, ... a monopoly over such features could be obtained without regard to whether they qualify as patents and could be extended forever (because trademarks may be renewed in perpetuity).”). 
generally maintained its emphasis on promoting linguistic clarity and preventing confusion and misinformation in the sales process. ${ }^{27}$ Initially, trademark law applied only to word marks, and conferred only the right to prevent competitors from using the mark on directly competing goods. ${ }^{28}$ Over time, however, trademark law has expanded both in subject matter and in scope. Federal trademark and unfair competition law now extend to product packaging, logos, and even the shape and features of products if consumers view these features as source-indicators. ${ }^{29}$ And often consumers do use these product features to identify source, at least with respect to certain well-known products: a chocolate aficionado, for example, would recognize immediately the shape and packaging of a Hershey's Kiss ${ }^{\mathrm{TM}}$, and would expect such a morsel to have the distinctive flavor associated with Hershey’s.

Just as trademark subject matter has expanded, so has the range of uses that can

${ }^{27}$ Initially, the law protected only against deception as to "the physical source or origin of the product or service with which the trademark was used." J. THOMAs McCARTHY, MCCARTHY ON TrAdEMARKS $\S 18: 39$, at p. 18-60 (1999). Over time, however, the courts recognized that trademarks could indicate quality as well as source, and extended protection to marks, such as franchise names, that indicated some consistent level of quality products or services. Id. at $\S 18: 40$. Further, the nationalization and internationalization of sales means that consumers can recognize and rely upon brands even if they don't know the actual source of the goods, so long as they understand that goods with the brand come from a consistent source. The law changed in 1984 to take account of this development. 15 U.S.C. $\S 1064(3)$ (amending genericness rule to overrule Anti-Monopoly, Inc. v. General Mills Fun Group, 682 F.2d 1316 (9 ${ }^{\text {th }}$ Cir. 1982)). In his treatise, McCarthy characterizes the shift as a move from a "source theory" of trademark protection toward a "quality theory." Id.

More recently, Congress created a new right for owners of famous marks, to prevent uses that "dilute" the distinctiveness of their marks. This right, too, finds some basis in the search costs rationale. See Stacey L. Dogan \& Mark A. Lemley, Trademarks and Consumer Search Costs on the Internet, 43 Hous. L. Rev. _ (forthcoming 2004)

${ }^{28}$ Hanover Star Milling Co. v. Metcalf, 240 U.S. 403, 412-13 (1916).

${ }^{29}$ McCarthy, supra note _, at $\S 1: 17$. 
subject one to an infringement or unfair competition claim. ${ }^{30}$ From its origins - in which infringement required the use of a similar mark on a directly competing product trademark law has expanded to control uses of a trademark on different but related goods "such that the ordinary buyer would be likely to think there was some connection or sponsorship between the producers or sellers of goods bearing a similar mark, even though the goods were non-competitive.”31 Trademark law, then, comes into play whenever consumers would presume affiliation, sponsorship, or other association between the trademark holder and another party selling goods under a similar mark. ${ }^{32}$ The law no longer limits itself to cases of "passing off" goods as manufactured or produced by the trademark holder. ${ }^{33}$

In the abstract, neither of these expansions departs from trademark law's core focus on facilitating the flow of truthful information and reducing consumer search costs. If consumers in fact perceive distinctive packaging as an indication of the qualities or source of the goods inside, then allowing trademark holders to prevent others from using

${ }^{30}$ The Lanham Act includes separate provisions for "infringement" of registered marks, on the one hand, and unfair competition through the use of confusingly similar symbols or devices, on the other. Compare 45 U.S.C. $§ 1114$ (providing a cause of action for infringement of registered marks) with 45 U.S.C. § 1125(a) (setting forth the standards for an unfair competition claim). For all practical purposes, however, the standards for infringement and unfair competition are identical, both turning on the existence of confusion as to affiliation, source, or sponsorship. The only significant difference for infringement purposes is the burden of proof: registered marks are presumed valid.

${ }^{31}$ McCarthy, supra note _, at § 24:2; see also Bone, supra note _, at [draft at 55-68].

${ }^{32}$ Congress codified this expansion in the Lanham Act, providing a cause of action against any person who falsely implies an "affiliation, connection or association" with a trademark holder, or causes confusion "as to the origin, sponsorship, or approval of his or her goods, services, or commercial activities....” 45 U.S.C. § 1125(a).

${ }^{33}$ More recently, Congress has extended federal trademark law to protect famous marks against the dilution of their distinctiveness. See infra notes _ _ _ and accompanying text. 
the same packaging will help consumers cheaply and easily to identify products from a consistent source. Similarly, if consumers view a mark as an indicator of consistent product quality, particularly in an economic environment in which companies regularly sell a large range of goods, it makes sense to enjoin confusing uses of the mark by sellers of related products, since consumers will suffer if their quality expectations are inaccurate. ${ }^{34}$

In combination, however, extending legal protection both to trade dress and to confusion based on sponsorship raises unique competition-related concerns that complicate the effect of such protection on the competitive process. As trademark law begins to protect not only the brand name for a product, but the product itself, it risks hindering competition rather than promoting it. If a manufacturer could use trademark law to prevent the copying of features that made its product superior in form or craftsmanship, consumers would suffer, because competitors could never enter the market for those features and drive prices down. ${ }^{35}$ The move from protecting trademark as label to trademark as mixed label-and-product, then, can have an ambiguous effect on competition: while it can potentially reduce search costs by facilitating product identification and reducing marketplace confusion, it can also directly hinder competition "on the merits" in the sale of products.

\footnotetext{
${ }^{34}$ This harm has both short-term and long-term dimensions. In the short term, consumers may suffer if the quality of a product fails to meet their expectations. Over the long term, if consumers learn that they cannot count on the trademark as a reliable indicator of quality, they will have to engage in more costly means of acquiring information about the quality of products. This latter effect represents the type of increase in consumer search costs that the trademark laws seek to avoid.

${ }^{35}$ See TrafFix Devices, Inc. v. Marketing Displays, Inc., 532 U.S. 23, 34-35 (2001).
} 
Trademark law has so far accommodated these competing concerns in two ways. First, with respect to product configuration (as opposed to packaging) trade dress, the Supreme Court recently clarified that protection applies only to features that actually, and demonstrably, indicate source to consumers. To claim trademark protection for a product feature, the claimant must prove that the feature has acquired secondary meaning, "which occurs when, 'in the minds of the public, the primary significance of a [mark] is to identify the source of the product rather than the product itself., ${ }^{36}$ If a product feature has achieved this status, the search costs rationale argues in favor of trademark protection, at least in the absence of some countervailing consideration. ${ }^{37}$ Second, even if a product feature has acquired secondary meaning, the "functionality" doctrine precludes protection if "its use as a mark would permit one competitor (or a group) to interfere with legitimate (non-trademark-related) competition through actual or potential exclusive use of an important product ingredient." ${ }^{38}$ The Supreme Court views functionality as the ultimate guardian of marketplace competition, and has, of late, repeatedly emphasized its significance. ${ }^{39}$ In tandem, the secondary meaning requirement and functionality doctrine

\footnotetext{
${ }^{36}$ Wal-Mart Stores, Inc. v. Samara Bros., Inc., 595 U.S. 205, 211 (2000) (quoting Inwood Labs, Inc. v. Ives Labs., Inc., 456 U.S. 851, n.11 (1982)). The trademark holder must also identify with particularity the features for which it seeks protection. Cf. Maharishi Hardy Blechman Ltd. v. Abercrombie \& Fitch Co., 292 F. Supp. 2d 535, 549-50 (S.D.N.Y. 2003) (rejecting trade dress claim based on product line that reflected inconsistency in product features).

${ }^{37}$ In other words, when a product feature has acquired secondary meaning, there is a risk that use of the feature by other sellers could confuse consumers as to source or sponsorship.

${ }^{38}$ Qualitex, 514 U.S. at 170.

39 See, e.g., Qualitex, 514 U.S. at 164 ("The functionality doctrine prevents trademark law, which seeks to promote competition by protecting a firm's reputation, from instead inhibiting legitimate competition by allowing a producer to control a useful product
} 
ensure that trademark law limits feature-based competition only when consumer expectations suggest that confusion is likely, and even then the primacy of competition requires that competitors have access to product features that are necessary to a competitive product market. We mention them here for two reasons: to emphasize that trademark law should have nothing to say about behavior that does not tamper with the clarity of information about who makes or sponsors products; and to reiterate that the law values such clarity only as long as it serves to promote a more competitive marketplace.

\section{B. The Merchandising Right and Trademark as Product}

Against this backdrop, the so-called "merchandising right" is something of an anomaly. When fans buy t-shirts with the name of their school, team, or rock band, they are almost always buying a product bearing an established mark entitled to some form of trademark protection. $^{40}$ But the mark in these cases is rarely serving the traditional function of a trademark. Rather than indicating something to the consumer about the

feature.”); TrafFix Devices, Inc. v. Marketing Displays, Inc., 532 U.S. 23, 34-35 (2001) ("The Lanham Act ... does not protect trade dress in a functional design simply because an investment has been made to encourage the public to associate a particular functional feature with a single manufacturer or seller.”); Two Pesos, Inc. v. Taco Cabana, Inc., 775 (the functionality doctrine "serves to assure that competition will not be stifled by the exhaustion of a limited number of trade dresses").

${ }^{40}$ Typically, the mark has acquired trademark status through use in connection with some other primary activity, such as baseball entertainment services, educational services, or music performance. As such, the mark serves as a source-indicator with respect to these services, and the trademark holder would have the right to prevent use of the mark on similar services or products.

By contrast, in Japan and increasingly in the United States people will sometimes buy T-shirts that display either an invented logo (one that doesn't in fact brand a real product) or a random collection of words. The case for merchandising protection for such invented logos is even weaker than for established trademarks. 
source or sponsorship of a product, the mark is the product, or at least is a critical part of what makes the product attractive. While the mark may, on occasion, also signal something about the source or sponsorship of the shirt, its function transcends the role of a traditional trademark. Merchandising cases therefore represent a kind of hybrid between product configuration and word-based trademark infringement claims: they generally involve protected marks, but the marks are more product features than brands.

For years, most trademark holders did not complain about such uses of their marks by unaffiliated parties. The Boston Athletic Association, which had operated the Boston Marathon since 1897, waited until the mid-1980s to object to the sale of BOSTON MARATHON merchandise by third parties. ${ }^{41}$ The University of Pittsburgh acquiesced in Champion Products' sale of PITT merchandise from 1936 until 1981, when it filed a trademark infringement suit. ${ }^{42}$ It appears that the 1970 s and 1980 s represented an era of awakening, in which trademark holders came to realize the economic value of their marks on merchandise and the revenues that they could earn through licensing if they were entitled to control the use of those marks. ${ }^{43}$ In the decades since, the awakening has only spread, to the point at which even municipal police departments are

${ }^{41}$ See Boston Athletic Ass’n v. Sullivan, 867 F.2d 22, 24-25 (1st Cir. 1989).

42 See University of Pittsburgh v. Champion Products, Inc., 529 F. Supp. 464 (D. Pa. 1982) (noting that University of Pittsburgh failed to object to unlicensed sales of PITT merchandise from 1936 until 1980); see also University Book Store et al. v. Board of Regents of University of Wisconsin, 1994 WL 747886, at *10 (T.T.A.B. 1994) (noting that University of Wisconsin had, "over the years, tolerated sales and advertising of goods, including clothing, bearing the marks” it sought to register in 1988).

43 Some of the sports leagues may have come to the realization a bit earlier. The National Football League, for example, established NFL Properties in 1963 expressly "to act as a licensing representative for the trademarks and other commercial identifications of the member clubs.” National Football League Properties, Inc. v. Wichita Falls Sportswear, Inc., 532 F. Supp. 651, 655 (W.D. Wash. 1982). 
entering the world of trademark licensing. ${ }^{44}$

\section{The Shaky Foundations of the Merchandising Right}

What explains the explosive growth of the licensing market for trademark merchandise? The answer appears to lie in a handful of judicial decisions from the 1970s and 1980s.

1975 was a banner year in the law of trademark merchandising. During that year, both the National Hockey League and the National Football League persuaded courts to enjoin the sale of unlicensed emblems bearing the marks of their member teams. ${ }^{45}$ While the Fifth Circuit NHL case received the most attention, the Illinois state court decision in the football case offered a more plausible - but more limited - theoretical justification for its extension of trademark doctrine. ${ }^{46}$ Together, the cases likely fueled the interest among trademark holders in obtaining royalties from the sale of their marks.

In Boston Hockey v. Dallas Cap \& Emblem, ${ }^{47}$ the National Hockey League and several of its member clubs brought suit to enjoin the manufacture and sale of emblems bearing their trademarks. ${ }^{48}$ The district court found no infringement, reasoning that

\footnotetext{
${ }^{44}$ See supra _-_.

${ }^{45}$ National Football League Properties, Inc. v. Consumer Enterprises, Inc., 327 N.E.2d 242, 247 (Ill. App. 1975); Boston Hockey v. Emblem Cap, 510 F.2d 1004, 1012 (5 ${ }^{\text {th }}$ Cir. 1975).

${ }^{46}$ See infra note __ and accompanying text.

${ }^{47} 510$ F.2d 1004, 1012 ( $5^{\text {th }}$ Cir.) (emphasis added), cert. denied, 423 U.S. 868 (1975).

${ }^{48}$ Id. at 1008.
} 
consumers did not necessarily expect an affiliation between the emblem seller and the hockey teams, ${ }^{49}$ and that in any event, the functionality doctrine required competitors to have access to trademarks that served as ornamental features on products. ${ }^{50}$

The Fifth Circuit's reversal broke new theoretical ground and effectively wrote the confusion requirement out of the Lanham Act. While conceding the centrality of confusion to trademark infringement claims, ${ }^{51}$ the court found the district court's concept of confusion unduly narrow:

It can be said that the public buyer knew that the emblems portrayed the teams' symbols. Thus, it can be argued, the buyer is not confused or deceived. This argument misplaces the purpose of the confusion requirement. The confusion or deceit requirement is met by the fact that the defendant duplicated the protected trademarks and sold them to the public knowing that the public would identify them as being the teams' trademarks. The certain knowledge of the buyer that the source and origin of the trademark symbols were in plaintiffs satisfies the requirement of the act. The argument that confusion must be as to the source of the manufacture of the emblem itself is unpersuasive, where the trademark, originated by the team, is the triggering mechanism for the sale of the emblem. $^{52}$

The court, in other words, presumed actionable confusion based solely on the

49 Boston Prof'l Hockey Ass’n, Inc. v. Dallas Cap \& Emblem Mfg., Inc., 360 F. Supp. 459, 462-63 (D. Tex. 1973) ("The test is not whether the products in question are duplications of their marks, but whether the defendant's use of the mark would mislead the public as to the source of the goods.”), rev'd, 510 F.2d 1004 (5 ${ }^{\text {th }}$ Cir. 1975).

${ }^{50} \mathrm{Id}$. at 463; see also id. at 464 ("The marks have achieved intrinsic value to a segment of the consuming public which may be attracted to their aesthetic features and to their characteristics as a patch to be used on apparel or for collecting. ... In this area of the economy the protection of trademark law must give way to the public policy favoring free competition.”). Recognizing, however, the possibility that at least some consumers might assume that the NHL had officially licensed the products, the court entered a limited injunction requiring a disclaimer of any association between the manufacturer and the NFL or its teams. Id. at 465.

51510 F.2d 1012.

${ }^{52}$ Id. (emphasis added). 
consumer's mental association between the trademark and the trademark holder. Likelihood of confusion, in the Boston Hockey definition, turns not on whether consumers have any misperception about where a product comes from or whether the trademark holder has endorsed it. On this approach, confusion exists by definition if the trademark comprises "the triggering mechanism” in the sale. ${ }^{53}$

What justified this shift in trademark theory? Without specifically addressing the district court's analysis of functionality, and while acknowledging that its decision "may slightly tilt the trademark laws from the purpose of protecting the public to the protection of business interests of plaintiffs," the court pointed to "three persuasive points" in support of its decision.

First, the major commercial value of the emblems is derived from the efforts of plaintiffs. Second, defendant sought and would have asserted, if obtained, an exclusive right to make and sell the emblems. Third, the sale of a reproduction of the trademark itself on an emblem is an accepted use of such team symbols in connection with the type of activity in which the business of professional sports is engaged. ${ }^{54}$

The second point is irrelevant, ${ }^{55}$ and the third circular: it amounts to arguing that allowing trademark holders to claim a royalty on merchandise bearing their marks is desirable because it's what trademark holders already do. ${ }^{56}$ None of these explanations even attempts to address the effect of such a right on consumers, on competitors, or on

${ }^{53} I d$.

${ }^{54} 510$ F.2d at 1011.

${ }^{55}$ Cf. Campbell v. Acuff-Rose Music, Inc., 510 U.S. 569, 585 \& n.18 (1994) (fact that party had unsuccessfully requested a license to use a copyrighted work should not weigh against fair use when the work is later used without permission).

${ }^{56}$ We address the "existing practices" argument in more detail infra note ___ _ and accompanying text. 
the competitiveness of the marketplace as a whole - i.e., on the core values of trademark law. The court's justification for departing from those core values quickly collapses to its first point - defendants are capturing commercial value that ought to belong to the plaintiffs. The decision - and indeed the merchandising theory altogether - finds its normative justification in an instinctive reaction against "unjust enrichment.”

Subsequent decisions and commentaries have condemned the Boston Hockey court's approach to likelihood of confusion in merchandise cases. ${ }^{57}$ Rather than presuming confusion based on the use of a known trademark, many if not most courts have required trademark holders to establish a genuine likelihood that the use will confuse consumers as to source, sponsorship, or affiliation. ${ }^{58}$ Without proof that

${ }^{57}$ See, e.g., United States v. Giles, 213 F.3d 1247, $1250\left(10^{\text {th }}\right.$ Cir. 2000) (criticizing Boston Hockey for its "reli[ance] upon a novel and overly broad conception of the rights that a trademark entails”); International Order of Job’s Daughters v. Lindeburg \& Co., 633 F.2d 912, 919 ( $9^{\text {th }}$ Cir. 1980) (describing decision as "an extraordinary extension of the protection heretofore afforded trademark owners"); Bi-Rite Enters, Inc. v. Button Master, 555 F. Supp. 1188, 1193-94 (S.D.N.Y. 1983); See Brown \& Denicola at 691 ( $7^{\text {th }}$ ed. 1998), noting that "Boston Hockey has been distinguished and limited in later decisions for its loose interpretation of the confusion requirement”); Withers, supra note —, at 453; Mark A. Kahn, May the Best Merchandise Win: The Law of Non-Trademark Uses of Sports Logos, 14 Marq. Sports L. Rev. 283, 302-09 (2004).

${ }^{58}$ See, e.g., University of Pittsburgh v. Champion Prods., Inc., 529 F. Supp. 464 (D. Pa. 1982); International Order of Job’s Daughters v. Lindeburg \& Co., 633 F.2d 912 (9 ${ }^{\text {th }}$ Cir. 1980); National Football League Properties, Inc. v. Wichita Falls Sportswear, Inc., 532 F. Supp. 651, 659 (W.D. Wash. 1982) ("Likelihood of confusion in a sponsorship context focuses on the product bearing the allegedly infringing marks and asks whether the public believes the product bearing the mark originates with or is somehow endorsed or authorized by the plaintiff."). The Fifth Circuit itself subsequently adopted this standard and thus narrowed, at least implicitly, the Boston Hockey holding. See Supreme Assembly, Order of Rainbow for Girls v. J.H. Ray Jewelry Co., 676 F.2d 1079, 1082 (5 ${ }^{\text {th }}$ Cir. 1982); Kentucky Fried Chicken Corp. v. Diversified Packaging Corp., 549 F.2d 368, 388 ( $5^{\text {th }}$ Cir. 1977) ("Trademark infringement occurs only when the use sought to be enjoined is likely to confuse purchasers with respect to such things as the product's source, its endorsement by the plaintiff, or its connection with the plaintiff.”).

The Restatement of Unfair Competition also impliedly rejects the merchandising 
consumers view a given use of a trademark as an indication of official sponsorship, these claims generally fail. In Board of Governors of University of North Carolina v. Helpingstine, ${ }^{59}$ for example, the court rejected UNC's infringement suit against a t-shirt manufacturer, based on a failure of proof that consumers viewed the shirts as sponsored by the university:

Given that there is a distinct possibility that individuals who buy products from Johnny T-Shirt do not base their decision upon whether the product is sponsored or endorsed by UNC-CH and that plaintiffs bear the burden of establishing likelihood of confusion, the court holds that UNC-CH must meet its burden by showing more than simply the identity of the marks. Instead, it must provide evidence establishing that individuals do make the critical distinction as to sponsorship or endorsement, or direct evidence of actual confusion. ${ }^{60}$

Other courts applying the confusion-based standard have similarly rejected the trademark holder's claims. ${ }^{61}$

Of the post-Boston Hockey courts that have found a likelihood of confusion in merchandising cases, most have based their decisions not on a new general right to

theory, stating in §25(1) that "one may be subject to liability under the law of trademarks for the use of a designation that resembles the trademark of another without proof of a likelihood of confusion only under an applicable antidilution statute." Comment $i$. then goes on to state that "use . . . as mere ornamentation on the subsequent user's goods does not dilute the distinctiveness of the mark by associating the mark as a symbol of identification with different goods or services.”

59714 F. Supp. 167 (M.D.N.C. 1989).

${ }^{60} \mathrm{Id}$. at 173 (citing McCarthy, supra note _, at $924: 3$ at 172).

${ }^{61}$ See, e.g., Supreme Assembly, Order of Rainbow Girls, 676 F.2d at 1083; University of Pittsburgh v. Champion Prods., Inc., 529 F. Supp. 464 (W.D. Pa. 1982); International Order of Job’s Daughters v. Lindeburg \& Co., 633 F.2d 912 (9 ${ }^{\text {th }}$ Cir. 1980); Board of Governors of University of North Carolina v. Helpingstine, 714 F. Supp. 167, 173 (M.D.N.C. 1989).

In a related context, a court recently refused to enjoin the sale of logos themselves as clip art. See Medic Alert Foundation v. Corel Corp., 43 F. Supp. 2d 933 (N.D. Ill. 1999). The court rejected the claim based on the absence of consumer confusion. Professor McCarthy endorses this result. McCarthy, supra note _, at 25:52.1. 
prevent unjust enrichment or control merchandising, but on evidence that the public actually believed the trademark holder licensed the defendant's products. ${ }^{62}$ This form of "sponsorship confusion" was the theoretical basis for the NFL's Illinois emblem suit in 1975. While the Illinois court was less than exacting in its analysis of the facts, ${ }^{63}$ later rulings in NFL suits have turned upon surveys and other evidence indicating the widespread belief that team-related jerseys are officially licensed by the League. ${ }^{64}$

Despite a general move away from its broadest reading, however, the residual effects of Boston Hockey remain, and later decisions sometimes fall back upon its conclusory language about the right of a trademark holder to control any uses that benefit from its mark's goodwill. ${ }^{65}$ Others, apparently moved by sympathy for the trademark

${ }^{62}$ Dr. Ing. h.c.F. Porsche AG v. Universal Brass, Inc., 1995 WL 420816, at*3 (W.D. Wash. 1995) (concluding that "actual confusion as to authorization, coupled with [defendant's] use of the [trademark registration] symbol, make it such that no rational trier of fact could find that confusion as to Porsche's sponsorship is unlikely"); National Football League Properties, Inc. v. Wichita Falls Sportswear, Inc., 532 F. Supp. 651, 659 (W.D. Wash. 1982).

${ }^{63}$ National Football League Properties, Inc. v. Consumer Enterprises, Inc., 327 N.E.2d 242, 246-47 (Ill. App. 1975) (basing likelihood of confusion conclusion upon the NFL's extensive licensing practices, through which "the buying public has come to associate the trademark with the sponsorship of the NFL or of the particular team involved").

${ }^{64}$ See, e.g., National Football League Properties, Inc. v. Wichita Falls Sportswear, Inc., 532 F. Supp. 651, 659 (W.D. Wash. 1982) ("Just as the relevant inquiry for the establishment of likelihood of confusion in a sponsorship context is the belief that sponsorship or authorization was granted, the inquiry should be the same in order to establish secondary meaning.”).

65 See, e.g., Boston Athletic Ass'n v. Sullivan, 867 F.2d 22, 33 (1 $1^{\text {st }}$ Cir. 1989) ("Defendants' shirts are clearly designed to take advantage of the Boston Marathon and to benefit from the good will associated with its promotion by plaintiffs. Defendants thus obtain a 'free ride' at plaintiffs' expense.”); University of Georgia Athletic Ass'n v. Laite, 756 F.2d 1535, 1547 (11 ${ }^{\text {th }}$ Cir. 1985) (enjoining use of BATTLIN' BULLDOG beer, when "the confusion stems not from the defendant's unfair competition with the plaintiff's products, but from the defendant's misuse of the plaintiff's reputation and good will as embodied in the plaintiff's mark”); Warner Bros., Inc. v. Gay Toys, Inc., 724 
holder, nominally focus on a likelihood of confusion but stretch the facts or adopt unsupported assumptions to conclude that consumers presume an association between the trademark holder and goods bearing its mark and will therefore be confused. ${ }^{66}$

These decisions, and the general uncertainty in the legal landscape surrounding merchandising rights, have no doubt contributed to trademark holders' intuition in favor of a licensing right. But they offer a rather slender reed on which to build an entire new jurisprudence. A closer look at these cases suggests that trademark holders may be relying on a proverbial house of cards. The fact that courts are at best evenly split as to whether a merchandising right even exists, and even more dubious of its existence in the absence of consumer confusion, ${ }^{67}$ makes it all the more surprising that trademark owners,

F.2d 327, 334 (2d Cir. 1983) ("It is because of that association, the identification of the toy car with its source, Warner's television series, that the toy car is bought by the public. That is enough" for an infringement claim against an imitator.) (emphasis in original); Sigma Chi Fraternity v. Sethscot Collection, 2000 WL 34414961, at *9 ("the confusion factor is met where, as here, the registered mark ... is the triggering mechanism for the sale of the product"); $c f$. University Book Store et al. v. Board of Regents of University of Wisconsin, 1994 WL 747886, at *8 (T.T.A.B. 1994) (criticizing the "antiquated view of trademarks as harmful monopolies which must be rigorously confined within traditional bounds" as "outmoded and not in accordance with more recent cases").

${ }^{66}$ See Boston Athletic Ass'n v. Sullivan, 867 F.2d 22, 33 ( $1^{\text {st }}$ Cir. 1989) (“Given the undisputed fact that (1) defendants intentionally referred to the Boston Marathon on its shirts, and (2) purchasers were likely to buy the shirts precisely because of that reference, we think it fair to presume that purchasers are likely to be confused about the shirt's source or sponsorship."); cf. University Book Store et al. v. Board of Regents of University of Wisconsin, 1994 WL 747886, at *10 (T.T.A.B. 1994) (acknowledging university's decades-long failure to police the use of its mark on merchandise, and nonetheless concluding that "it is undisputed that, to a significant portion of the relevant public, the subject marks identify applicant as the primary source of its educational and entertainment services and as the secondary source of the apparel imprinted with such marks") (emphasis added).

67 This doctrinal disagreement is not limited to the United States. In Arsenal Football Club v. Reed, [2003] EWCA Civ. 96 (Ct. App. Chanc.), the European Court of Justice established a merchandising right, holding that if both the marks and the goods sold were identical it did not matter whether consumers were confused. The U.K. courts refused to 
retail businesses and even government officials simply assume the existence of such a right. $^{68}$

\section{Does the Merchandising Right Make Sense?}

In this section, we consider the pros and cons of a broad merchandising right, and conclude that there is no theoretical and little practical justification for such a right. At best, trademark owners are entitled to prevent a limited range of merchandising uses that are likely to confuse consumers.

\section{A. Goodwill and Free Riding}

To begin, we will consider the theory of unjust enrichment or free riding that seems to underlie the instincts of courts and trademark owners in many of the merchandising cases. Advocates of the merchandising right justify it by referring to the "free riding” that would occur if competitors could sell T-shirts using their logos. Those competitors would be "trading on their goodwill," and therefore presumably taking something that ought as a matter of right to belong to the trademark owner. ${ }^{69}$ Courts

give effect to this judgment, however, ruling that it was beyond the jurisdiction of the ECJ and that Reed's sale of merchandise featuring the logo of the Arsenal football team did not infringe Arsenal's trademark.

68 See, e.g., James Cyphers, Companies Join Police in Pursuing T-Shirt Bootleggers, Wall St. J., Sept. 4, 1991, at B2 (noting law enforcement actions against the sale of tshirts bearing trademarks and logos).

69 Jerre B. Swann \& Theodore H. Davis Jr., Dilution, An Idea Whose Time Has Gone: 
sometimes talk loosely about appropriation of a trademark owner's goodwill as the harm to be prevented. ${ }^{70}$ In a related vein, Robert Denicola concludes that while a merchandising right doesn't fit well with trademark theory, the trademark owner has a better claim to own the right than anyone else, and so deserves the right to control merchandising using the trademark. ${ }^{71}$

These justifications are circular and ultimately empty. Denicola's analysis presumes that someone must control this particular segment of the market. If we start our analysis on that basis, it might make sense that the trademark owner is the logical entity to exercise that control. ${ }^{72}$ But there is no reason to start from that presumption. We do not assume that the trademark owner has the right to control parodies, or criticism, or referential uses of the mark, or "uses" of a mark based on proximity. ${ }^{73}$ Trademark rights have never given exclusive rights to control all uses of a mark. They have traditionally given trademark owners the right only to prevent uses that confuse consumers, or blur the

Brand Equity as Protectable Property, the New/Old Paradigm, 1 J. Intell. Prop. L. 219, 238 (1994); Marlene B. Hanson \& W. Casey Walls, Protecting Trademark Good Will: The Case for a Federal Standard of Misappropriation, 81 Trademark Rptr. 480 (1991). Many would trace this notion back to Frank Schechter, who conceived of trademarks as property rights long before the notion was in judicial vogue. See Frank I. Schechter, The Rational Basis of Trademark Protection, 40 Harv. L. Rev. 813, 819 (1927).

70 See, e.g., Beacon Mutual Ins. Co. v. OneBeacon Ins., 376 F.3d 8 ( $1^{\text {st }}$ Cir. 2004); 1-800 Contacts v. WhenU.com, 309 F. Supp. 2d at 490 (S.D.N.Y. 2004); Brockum Co. v. Blaylock, 729 F. Supp. 438, 444 (E.D. Pa. 1990) (the "unlicensed use of the Rolling Stones' name" on t-shirts "would permit the defendant to reap where it had not sown").

${ }^{71}$ See Denicola, supra note _, at 640-41.

72 Even then this conclusion is not inexorable. Since consumers are the ultimate intended beneficiaries of trademark protection, one could argue that it made more sense to vest such a right in consumers, not producers.

73 For a discussion of non-trademark uses that are protected, see Dogan \& Lemley, supra note _, at _. 
distinctive significance of the mark, in order to minimize consumer search costs and facilitate the functioning of large-scale markets. Uses of a mark that don't raise these concerns are reserved to the free market. The merchandising theory expands the rights of trademark owners, giving them a new form of control over uses of "their" mark at the expense of the background norm of competition. ${ }^{74}$ That expansion requires some justification; in a market economy it is not reasonable to simply assume that someone must own the right to compete in particular ways. ${ }^{75}$

This justification cannot be found in the notion of "free riding" or appropriation of goodwill. Those notions too assume rather than demonstrate that someone is entitled to own a right on which another might free ride. ${ }^{76}$ We don't speak of newspapers as "free riding” on trade names when they report news about the companies that use those names, even though one can imagine a world in which the trademark owner licensed such use. Similarly, we don't speak of gas stations as free riding on competitors when they locate across the street from that competitor, or of stores free riding on the anchor tenant of a shopping mall by deciding to lease space in that mall. Companies engaging in all these activities are free riding in some sense; they are using the name or reputation of another

74 As Ralph Brown put it, "competition is copying." Ralph S. Brown, The Joys of Copyright, 30 J. Copyright Soc'y 477, 481 (1983). See also Robert C. Denicola, Freedom to Copy, 108 Yale L.J. 1661, 1661 (1999) ("laws that restrain copying . . . restrain competition").

75 See generally Peter Jaffey, Merchandising and the Law of Trade Marks, 3 INTELL. PROP. Q. 240, 240-42 (1998) (noting that trademark law does not support a general merchandising right).

76 Mark Lemley deconstructs the idea of free riding as a justification for an intellectual property regime in Mark A. Lemley, Property, Intellectual Property, and Free Riding (working paper 2004). 
company without paying. But the world is full of free riding. ${ }^{77}$ The question is whether a particular type of conduct causes the kind of harm that trademark law ought to address. ${ }^{78}$ Simply announcing that a particular use of a trademark is an improper appropriation of the trademark owner's goodwill assumes the conclusion. ${ }^{79}$

The problem is not simply that we can't find an affirmative reason to grant trademark owners a merchandising right. Doing so can actually interfere with the fundamental goals of trademark law, as we discuss in the next section.

77 See Wendy J. Gordon, On Owning Information: Intellectual Property and the Restitutionary Impulse, 78 Va. L. Rev. 149, 167 (1992) ("A culture could not exist if all free riding were prohibited within it."); see also TrafFix Devices, Inc. v. Marketing Displays, Inc., 532 U.S. 23, 29 (2001) ("In general, unless an intellectual property right such as a patent or copyright protects an item, it will be subject to copying. ... Allowing competitors to copy will have salutary effects in many instances.”).

${ }^{78}$ Certainly, free riding may sometimes threaten incentives or distort information in the marketplace. But the structure of our intellectual property system already addresses these forms of free riding, in a way that strikes a balance between incentive and competition. Patent and copyright laws, for example, insulate creators from copying creative works or inventions for a defined term, in order to provide them with an incentive to create works that ultimately are relegated to the public. Trademark law targets free riding only if it misleads consumers and thus distorts information in the marketplace. While one might imagine an argument that a merchandising right helps to provide financial support for trademark holders' primary activity, such an argument turns on unfounded assumptions that such support is necessary and appropriate, and that information-based trademark law is the best vehicle to provide it. See infra note

79 Rochelle Dreyfuss has derided such assumptions as "if value, then right." Rochelle Cooper Dreyfuss, Expressive Genericity: Trademarks as Language in the Pepsi Generation, 65 Notre Dame L. Rev. 397, 405 (1990). See also Felix Cohen, Transcendental Nonsense and the Functional Approach, 35 Colum. L. Rev. 809, 815 (1935) ("The vicious circle inherent in this reasoning is plain. It purports to base legal protection upon economic value, when, as a matter of actual fact, the economic value of a sales device depends upon the extent to which it will be legally protected."); William P. Kratzke, Normative Economic Analysis of Trademark Law, 21 Memphis St. U. L. Rev. 199, 203-04 (1991). 


\section{A. Harms of a Broad Merchandising Right}

Why not grant trademark owners a right to control merchandising of their logos? The answer begins with the fundamental justification of trademark law: improving the functioning of the market by reducing consumer search costs. From a search costs perspective, a general merchandising right unmoored from confusion conflicts with, rather than promoting, trademark law's pro-competitive goals. If consumers are not duped into believing that a trademark-bearing product was either sponsored or made by the trademark holder, ${ }^{80}$ then the quality of product-related information in the marketplace has not suffered from the use. ${ }^{81}$ And the overarching goal of market competition will only gain: the unlicensed product will presumably compete in the marketplace with any licensed versions, bringing prices down, letting consumers choose higher-quality products with identical logos, and generally benefiting the consumer. On balance, then, non-confusing uses of marks on merchandise serve, rather than impede, competition in the marketplace, thus promoting the overall goals of trademark and unfair competition law.

Trademark law facilitates market competition by permitting consumers to find

${ }^{80}$ Compare Dr. Ing. h.c.F. Porsche AG v. Universal Brass, Inc., 1995 WL 420816, at *3 (W.D. Wash. 1995) (finding confusion based on use of registered Porsche trademark, together with @ symbol, which suggested official sponsorship by Porsche); $c f$. Bi-Rite Enters, Inc. v. Button Master, 555 F. Supp. 1188, 1193-94 (S.D.N.Y. 1983) (suggesting that confusion as to sponsorship of band paraphernalia may exist when the merchandise is sold at concerts and other contexts in which consumers may assume official sponsorship).

${ }^{81}$ See, e.g., Board of Governors of University of North Carolina v. Helpingstine, 714 F. Supp. 167, 173 (M.D.N.C. 1989) ("In essence, the court is skeptical that those individuals who purchase unlicensed tee-shirts bearing UNC-CH's marks care one way or the other whether the University sponsors or endorses such products or whether the products are officially licensed.”). 
products cheaply and quickly by relating advertising and their own experiences to the products they buy. An infringement of a trademark is one that increases consumer search costs, normally by confusing consumers. Trademarks can extend not only to words and logos, but to trade dress and even the color or shape of a product. But trademark law does not give rights over an entire product class, because doing so would short-circuit the very market competition trademark law is supposed to protect. ${ }^{82}$ Similarly, a merchandising right would give rights over irreplaceable product features, which inevitably increases the cost of those products. If only one company controls the sale of Seattle Seahawks T-shirts, those shirts will cost more and be of worse quality than if the market competes to provide those shirts. ${ }^{83}$ Consumers lose something tangible - they pay more for the shirt, or they are unable to express their support for the Seahawks because they can't afford the shirt, or they get a lower quality shirt. There must be some reason for the law to compel that loss.

The Boston Hockey approach has no logical stopping point. It conflicts with the text of the Lanham Act, which makes infringement turn not on mental association, but on confusion, deception, or mistake. ${ }^{84}$ More significantly, it leaves us without an effective standard for determining when a use of a trademark is legal. The merchandising right

82 See, e.g., Wal-Mart Stores, Inc. v. Samara Bros., 529 U.S. 205 (2000) (refusing to protect product configurations as trademarks unless consumers view them as such); TrafFix Devices, Inc. v. Marketing Displays, Inc., 532 U.S. 23 (2001) (refusing to extend trademark protection to aspects of products that improve their performance).

83 See Paul J. Heald, Filling Two Gaps in the Restatement (Third) of Unfair Competition: Mixed-Use Trademarks and the Problem with Vanna, 47 S.C. L. Rev. 783, 788-89 (1996).

${ }^{84} 45$ U.S.C. $\S \S 1114(a), 1125(a) ;$ see generally Stacey L. Dogan, An Exclusive Right to Evoke, 44 B.C. L. Rev. 291 (2003). 
cases seem to stem from the unjust enrichment instinct that "if value, then right." ${ }^{\text {" }}$ But as we have explained elsewhere, that instinct has no solid basis in public policy. ${ }^{86}$ It would make each of the countless "nominative uses" trademark law permits into infringements. ${ }^{87}$ And it would turn trademark law from a right designed to facilitate commerce into a right to control language, something the courts have repeatedly warned against given its troubling implications for both competition and free speech. ${ }^{88}$ College students and football fans couldn't support their team unless they paid the required fee. ${ }^{89}$ Newspapers might be at risk for using brand names or logos in connection with their stories. Aqua couldn't sing the song "Barbie Girl,"90 or Walking Mountain create art using Barbie dolls, ${ }^{91}$ even though consumers weren’t confused. Individuals might even

85 Rochelle Cooper Dreyfuss, Expressive Genericity: Trademarks as Language in the Pepsi Generation, 65 Notre Dame L. Rev. 397, 405 (1990).

86 See Dogan \& Lemley, Keywords, supra note __; Lemley, Free Riding, supra note _.

${ }^{87}$ See, e.g., New Kids on the Block v. News America Publishing, 971 F.2d $302\left(9^{\text {th }}\right.$ Cir. 1992) (permitting unlicensed use of a trademark to refer to its owner, even when used by the defendant for commercial advantage).

88 See, e.g., CPC Int'l v. Skippy, Inc., 214 F.3d 456 (4 ${ }^{\text {th }}$ Cir. 2000); Nissan Motor Co. v. Nissan Computer Corp., _ F.3d _, 2004 WL 1753289 (9 $9^{\text {th }}$ Cir. Aug. 6, 2004). For a discussion of trademarks and the First Amendment, see, e.g., Mark A. Lemley \& Eugene Volokh, Freedom of Speech and Injunctions in Intellectual Property Cases, 48 Duke L.J. 147, 216-24 (1998).

${ }^{89}$ Cf. University Book Store et al. v. Board of Regents of University of Wisconsin, 1994 WL 747886, at *10 (T.T.A.B. 1994) (prior to applying to register its marks with the Patent and Trademark Office, "Applicant, like numerous other colleges and universities, permitted others to sell imprinted merchandise as expressions of community support and goodwill.”); see generally Jeffrey Zaslow, Sports Fans Snap up Souvenirs of Winners Beating Losers: Mascot Boiled or Grilled?, Wall St. J., Nov. 12, 2003, at A1 (describing the increased demand for "rivalry merchandise" mocking competitors' mascots, and the growth in licensed versions of such products in which universities control the message).

90 Mattel, Inc. v. MCA Records, Inc., 296 F.3d 894 ( $9^{\text {th }}$ Cir. 2002) (permitting this use).

91 Mattel, Inc. v. Walking Mountain Productions, 353 F.3d 792 (9 $9^{\text {th }}$ Cir. 2003) (permitting this use). 
be liable for wearing tattoos or jewelry containing trademarked logos, or tattoo parlors for applying them. ${ }^{92}$

Further, accepting free riding as the basis for a merchandising right would encourage courts more generally to focus on "free riding" and "trading on goodwill" as inherent evils, ${ }^{93}$ and to move toward a presumption of illegality for any use of someone else’s trademark. Limiting doctrines like "trademark use” and perhaps even "nominative use” have already proven challenging for courts to apply because of the temptation to assume that any use of a trademark must necessarily be a bad one. This doesn't mean trademark law will lose all its defenses. The First Amendment will continue to protect certain uses of a trademark, particularly in parody and news reporting. But the structural limits on the scope of trademark and dilution law are intellectually harder to maintain if we simultaneously treat the same marks as pure property rights in the merchandising context.

To be sure, we might try to cabin the merchandising right so that it doesn't reach desirable uses. But to do so we would need a theory of merchandising control that is broader than consumer search costs and the avoidance of confusion, but not as broad as

92 For a discussion of this possibility, see Thomas F. Cotter \& Angela M. Mirabole, Written on the Body: Intellectual Property Rights in Tattoos, Makeup, and Other Body Art, 10 UCLA Ent. L. Rev. 97, 123-31 (2003). Cotter and Mirabole conclude that the individual would not be liable under current law, and that the tattoo parlor shouldn't be either, though the question is closer.

93 A merchandising right seems more like a physical property right than traditional trademark law does. For criticism of treating trademarks as property, see Mark A. Lemley, The Modern Lanham Act and the Death of Common Sense, 108 Yale L.J. 1697 (1999). But the two are not coextensive. It is possible to treat trademarks as property in certain respects - for example, permitting them to be sold or used as security interests, see Xuan-Thao N. Nguyen, Bankrupting Trademarks, 37 U.C. Davis L. Rev. 1267 (2004) - without necessarily extending protection to any use of a logo. 
unjust enrichment or appropriation of goodwill. As we will find in the next sections, such a justification for the merchandising right is hard to come by.

\section{Preserving Existing Expectations}

Even absent a good theoretical justification for a broad merchandising right, advocates might fall back on a practical concern. It seems clear that trademark owners assume they have a right to control merchandising. Wouldn't it upset the settled expectations of those trademark owners to suddenly nullify the right? Similarly, might consumers be confused if they too believe that any T-shirt bearing a corporate logo is licensed by the corporation?

The first concern need not detain us long. First, based on our review of the cases in Part I, it is far from clear that trademark owners are reasonable in assuming the existence of such a right. The case law support for it has never been strong or unequivocal. Second, there is no obvious investment that will be lost if the broad merchandising theory is rejected. Trademark owners won't lose their protection against consumer confusion or dilution. Nor can the trademark owner make a plausible case that a competing sale of, say, Dallas Cowboys hats will weaken the connection between the mark and the team. True, the Cowboys might make less money than they would if trademarks were absolute property rights, and they might argue that this "discourages investment” in football. But so what? The point of trademark law has never been to maximize profits for trademark owners at the expense of competitors and consumers. And the investment at issue in these cases is not investment in the quality of the 
underlying product (the team), but investment in merchandising the brand itself. As Ralph Brown quite sensibly suggested, this is not the goal of the law. ${ }^{94}$

The consumer concern is a more significant one. It is possible that consumers have come to expect that San Francisco Giants jerseys are licensed by the Giants, not because they serve a brand-identifying function, but simply because the law has sometimes required such a relationship. ${ }^{95}$ Indeed, the NFL cases we discussed above found evidence of this. If this expectation exists, consumers may be confused if the law changes. If so, a law based on eliminating consumer confusion may be obliged to give trademark owners the right to prevent such uses in order to avoid this confusion.

Or perhaps not. Glynn Lunney derides this sort of confusion argument as circular, ${ }^{96}$ and of course in some sense it is. The idea that once-legal conduct becomes illegal simply because the public believes it is illegal seems like bootstrapping. ${ }^{97}$ But if we are committed to basing trademark doctrine on consumer reactions, we might be stuck

94. See Ralph S. Brown Jr., Advertising and the Public Interest: Legal Protection of Trade Symbols, 57 Yale L.J. 1165, 1177-80 (1948). Others have echoed this view. See Felix Cohen, supra note _, at 815; Julie E. Cohen, Lochner in Cyberspace: The New Economic Orthodoxy of Rights Management, 97 Mich. L. Rev. 462, 506-14 (1998); Heald, supra note _ , at 791-92; Litman, supra note _ at _.

95 Rob Denicola cites consumer surveys presented in merchandising cases that support this conclusion. See Denicola, Freedom to Copy, supra note _, at 1668 n. 37.

${ }^{96}$ Lunney, supra note _, at _.

97 Some courts have taken the merchandising right so far as to conclude that "consumer confusion" may occur where consumers are not in fact confused about the relationship between the two products, but nonetheless believe that the defendant might have needed a license to use the mark. See Anheuser-Busch v. Balducci Publications, 28 F.3d 769, 775 (8th Cir. 1994); accord Pebble Beach Co. v. Tour 18 I Ltd., 155 F.3d 526, 544-45 (5th Cir. 1998). For criticism of this approach, see, for example, Lunney, supra note (manuscript at 31, 43), who suggests that this approach is intellectually dishonest, and Tyler T. Ochoa, Dr. Seuss, The Juice and Fair Use: How the Grinch Silenced a Parody, 45 J. Copyright Soc’y 546, 624 (1998). 
with those reactions even if bad legal decisions initially helped create them. The real underlying issue is whether the trademark law should act here as a creator or as a reflector of societal norms. ${ }^{98}$ In the context of likelihood of confusion analysis, trademark law has traditionally adapted itself to reflect societal norms, rendering a use illegal if but only if it confuses consumers. In other areas, however, trademark law acts as a norms creator, establishing standards that shape rather than merely respond to consumer beliefs. The law creates certain limiting doctrines - genericide, trademark use, and fair use, for example - that constrain the scope of trademark rights and that exist whether or not the public is aware of them. ${ }^{99}$ Trademark's norm-creation role is important because it prevents a downward spiral in which the court focuses on the most gullible consumers, lowering the standards and expectations of others. ${ }^{100}$ Rigorous application of these doctrines can affect consumer perceptions. In effect, the law is leading rather than following consumer expectations.

The merchandising theory presents a difficult problem in choosing between these functions. On the one hand, the merchandising theory is an effort to expand the basic scope of trademark protection beyond its usual bounds. Thus, it seems analogous to other limiting doctrines that are intrinsic to the law, not dependent on consumer expectations.

98 Graeme Dinwoodie, 43 Hous. L. Rev. _ (forthcoming 2004); Dogan \& Lemley, supra note _, at _.

99 See Dogan \& Lemley, supra note _ , at _ (discussing the role of trademark law as a norms creator in creating limiting doctrines like trademark use). There is currently a split in the circuits as to whether the fair use doctrine is independent of consumer confusion, or requires proof of the absence of confusion. The Supreme Court will resolve that issue - and have an opportunity to address the norm creator/norm follower distinction - this year in the KP Holdings case.

100 See Litman, Breakfast With Batman, supra note _ at _. 
As Robert Denicola has pointed out, the role of trademark law as norms creator may be especially important in merchandising cases. Unlike the ordinary trademark case, in which an infringing defendant can simply choose another mark and compete fairly in the relevant market, "a defendant enjoined from using a well-known insignia on T-shirts or caps is effectively excluded from the market. It can sell to no one, including those who care not the slightest whether their Boston Red Sox cap is licensed or approved.”101 On the other hand, if it is correct that consumers now believe T-shirts are sponsored by the owner of the logos emblazoned on them, that assumption seems to fit within the likelihood of confusion analysis as to which trademark law has traditionally been a norms reflector.

We are inclined to believe that this is a case in which the law should act as a norms creator. In part this is because any consumer confusion is itself an artifact of legal cases that seemed to create a new merchandising right; arguably it should be up to the courts, not consumers, to undo the problems a few ill-considered decisions may have created. This is particularly so when consumers' belief that the law requires permission to use a logo may not matter at all to their assessment of the quality of the merchandise at issue, such as when the product prominently identifies its manufacturer. ${ }^{102}$ If individuals don't "care one way or the other whether [the trademark holder] sponsors or endorses such products or whether the products are officially licensed," ${ }^{103}$ then the competitive

${ }^{101}$ Denicola, supra note _, at 613.

102 Cf. Greater Anchorage, Inc. v. Nowell, 974 F.2d 1342 (Table) (9 ${ }^{\text {th }}$ Cir. 1992) (rejecting merchandising claim, when "customers actually believed the pins were 'illegal.' Thus, there is no evidence that people actually believe that [defendant's] pins are associated with” plaintiff).

103 Board of Gov. of Univ. of N.C. v. Helpingstine, 714 F. Supp. 167, 173 (M.D.N.C. 
process certainly does not suffer from their assumption that the use required a license.

A second reason for courts not to blindly defer to consumer norms in merchandising cases is that the law can likely cure most confusion of this type without eliminating competition, simply by requiring a conspicuous disclaimer. Some courts have tried to steer a middle ground by permitting such uses but requiring that the user take all reasonable steps to try to reduce confusion both at the point of purchase and postsale. ${ }^{104}$ Robert Bone suggests that the law should aggressively create norms here and rule that a disclaimer is the sole remedy in all merchandising cases. We would not go that far. As we note in the next section, there may be rare instances of post-sale confusion that would not be cured by a disclaimer.

How would a disclaimer-based analysis proceed? As an initial matter, the plaintiffs would have to prove consumer confusion. We haven't seen sufficient evidence to persuade us that consumers do in fact think this way in a significant number of cases. A merchandising right based on a likelihood of confusion as to sponsorship should require proof of likely consumer confusion, just as any other trademark infringement claim. ${ }^{105}$ If consumers don’t assume sponsorship from the use of a logo on a T-shirt, or if a conspicuous disclaimer would be sufficient to cure any such confusion, there is no basis for granting the trademark owner merchandising protection.

1989).

104 See, e.g., Plasticolor Molded Prods. v. Ford Motor Co., 713 F. Supp. 1329, 1338-39 (C.D. Cal. 1989) (Kozinski, J., sitting by designation). See also Note, Promotional Goods and the Functionality Doctrine: An Economic Model of Trademarks, 63 Tex. L. Rev. 639, 664-69 (1984).

105 See also Withers, supra note _, at 453 (arguing that merchandising should be illegal only where consumers are likely to be confused). 
There are lots of famous marks and icons for which we have not granted merchandising rights. No one controls the exclusive right to make "Statue of Liberty" tshirts or paperweights, for example. And while consumers might make this assumption in the context of some famous marks, particularly in the field of professional sports, ${ }^{106}$ there are many more marks for which there is no evidence that consumers expect the trademark owner to be the only manufacturer. ${ }^{107}$ Even if we decide we cannot undo what some cases have done in the sports context, there is no reason to extend the merchandising right any further, since it is hard to find any theoretical or statutory basis for the property approach to trademarks. ${ }^{108}$

One policy argument sometimes raised in favor of granting merchandising rights is that it provides needed financial support for the trademark owner. ${ }^{109}$ This is a slightly altered form of the argument that merchandise rights serve as incentives, an argument

106 The National Football League, in particular, has had considerable success in establishing that consumers assume it has licensed uses of NFL team logos and other trademarks. See, e.g., National Football League v. Governor of the State of Delaware, 435 F. Supp. 1372, 1381 (D. Del. 1977) ("Apparently, in this day and age when professional sports teams franchise pennants, teeshirts, helmets, drinking glasses and a wide range of other products, a substantial number of people believe, if not told otherwise, that one cannot conduct an enterprise of this kind without NFL approval.”).

107 See Denicola, supra note _ , at 612 ("If the NFL successfully establishes a reputation for aggressively marketing its insignia, we may readily assume its sponsorship of book bags marked with the logo of the Dallas Cowboys, yet refrain from an analogous attribution of sponsorship for bags displaying the mascot of the local high school.”); see also id. (discussing other contexts in which assumption of sponsorship may be more likely, such as musician-related sales occurring at concert sites rather than at other locations).

108 Judge Kozinski suggests that a case-by-case balancing approach is appropriate in these circumstances. See Kozinski, supra note _, at 971.

109 See, e.g., Withers, supra note _, at _ (noting this argument). 
that has been soundly refuted elsewhere. ${ }^{110}$ Merchandise may be an indirect way of subsidizing colleges and other trademark owners, though we are skeptical that the argument has much persuasive force when applied to corporations such as Nike or CocaCola rather than to universities. But if the goal of consumers is to contribute to the school, there are other, more direct ways of doing so. Indeed, if consumers do in fact value obtaining goods from the trademark owner itself - perhaps because it supports the school or team - then we would expect the market to reflect that by developing a distinction between ordinary merchandise and officially licensed merchandise. This may reflect the best of all worlds, because consumers will learn whether merchandise is sponsored by the trademark owner or not, and can choose their goods accordingly. ${ }^{111} \mathrm{~A}$ requirement of a conspicuous disclaimer would help such a market develop. The emphasis in merchandising inquiries would appropriately shift, then, to whether the defendant had deceptively suggested that its goods were officially licensed by the trademark holder. ${ }^{112}$ That is something within the traditional competence of trademark

110 See, e.g., Veronica J. Cherniak, Ornamental Use of Trademarks: The Judicial Development and Economic Implications of an Exclusive Merchandising Right, 69 Tul. L. Rev. 1311, 1349-52 (1995). Among other problems, Cherniak notes that unlike copyrighted works, there is no particular reason to encourage the creation of new trademarks; that trademark owners already have substantial incentive to invest in their brands because of the association between those brands and their products; and that there are other ways for companies to capitalize on the positive value of their goodwill.

111 Scott Kieff even goes so far as to suggest that this distinction can replace copyright, because even without copyright customers will voluntarily choose to support favored artists. F. Scott Kieff, The Case Against Copyright: A Comparative Institutional Analysis of Intellectual Property Regimes (working paper 2004). One does not have to go this far to believe that consumers may choose to support affinity groups by opting to purchase licensed products.

112 See Denicola, supra note _, at 613; see, e.g., Kentucky Fried Chicken Corp. v. Diversified Packing Corp., 549 F.2d 368, 383 ( $5^{\text {th }}$ Cir. 1977) (finding trademark violation when defendant's advertisements contained cartoons similar to plaintiff's cartoons and called for customers to "Buy Direct and Save”); Wyatt Earp Enters. v. Sackman, Inc., 
law, and a task courts are well-equipped to perform.

We conclude, therefore, that the fact that consumers may believe trademark owners have a right to control merchandise bearing their brands doesn’t itself justify a merchandising right. The issue is certainly not free from doubt, and we can readily imagine a court concluding that even if the merchandising theory is unpersuasive, we have gone too far down that road to turn back now. But even if a court were to take that position, a limited, likelihood-of-confusion rationale for keeping a bad law intact is quite different from a theoretical justification for cementing and extending the merchandising right.

\section{The Scope of Counterfeiting Law}

A third concern with eliminating the merchandising right is that it might interfere with efforts to prevent certain types of counterfeiting. Counterfeiting is the canonical case of trademark infringement. A defendant copies the trademark owner's brand or mark and affixes it to goods identical in appearance to the trademarked goods, passing its own goods off as the trademark owner's. There is no question that counterfeiting violates the trademark laws because it confuses consumers; indeed, it is also a crime. ${ }^{113}$ This

157 F. Supp. 621, 625 (S.D.N.Y. 1958) (enjoining sale of unlicensed costumes whose boxes were stamped "official outfit”).

11318 U.S.C. $\S 2320$. It is worth noting, however, that that statute does not expand trademark liability, but rather provides that all the limitations on and defenses to the Lanham Act apply to it as well. Id. § 2320(c). At least one court has held that the statute does not apply to the sale of trademarks as products, rather than as labels for goods that imitate the trademark holder's. United States v. Giles, 213 F.3d 1247 (10 ${ }^{\text {th }}$ Cir. 2000). 
form of passing off has little to do with a merchandising right, since ordinary trademark law seems perfectly well suited to deal with it.

Suppose, however, that the circumstances of the counterfeit sale are sufficient to dispel any buyer confusion. The example often cited is a fake Rolex watch bought on the street corner for $\$ 20 .{ }^{114}$ The buyer of the fake Rolex presumably doesn't believe he is getting the real thing. Nonetheless, there seems something intuitively wrong with permitting the copying of the Rolex trademark, even in circumstances where the buyer knows what they are getting. Similarly, one might think that sellers of "knock-off” Prada handbags, Chanel perfumes, or Nike T-shirts are causing harm of some sort to the trademark owner, even if it is not the classic harm of displaced sales. One benefit of a merchandising right would be to create a cause of action against those who copy trademarked goods even in the absence of consumer confusion.

It's worth exploring further the intuition that the copier's conduct is wrongful. There seem four possible bases for such an intuition. First, there may be concerns about actual confusion. Take Nike. Because Nike is an apparel manufacturer, consumers who see a T-shirt with the familiar "swoosh" on it may well assume that Nike is selling the Tshirt, even if they really want the shirt because they think the swoosh looks cool, not because they think Nike makes high-quality clothing. If consumers do in fact think Nike is selling the T-shirt, the likely legal effect will be that Nike gets control over the swoosh, at least on clothing. ${ }^{115}$ This control seems similar to what a merchandising right would

114 See, e.g., Kozinski, supra note _, at _.

115 The issue here is a bit different from the norm creator-norm enforcer distinction we discussed above. There, the question was whether consumers believed the mark must be 
give. But that is an accident of the fact that Nike is an apparel manufacturer, and it is reasonable to assume that they will make and sell T-shirts as well as shoes. A right based on such actual confusion would not protect Nike against the use of swooshes on kitchenware; nor would it protect Coca-Cola against the use of its logo on T-shirts. It is not a merchandising right, but simply an application of traditional principles of consumer confusion. Further, this sort of traditional confusion may well be dispelled by an appropriately conspicuous disclaimer.

A second concern that might justify a prohibition against copying of logos is the fear that even though the buyer isn’t confused, others might be. Assuming that the \$20 fake Rolex looks like the real one, even if I know that I bought the fake one, others may not be able to tell the difference. This in turn can cause harm; if people see Rolexes that don't tell time well, or break, they may mistakenly attribute the shoddy quality of the counterfeit goods to the trademark owner. Traditional trademark law deals with this problem under the rubric of "post-sale confusion." This was the situation in Lois Sportswear v. Levi Strauss \& Co. ${ }^{116}$ There, Levi Strauss had registered not only its trade name and its jean labels, but also the pattern of stitching on the back pockets of its jeans. Lois Sportswear sold jeans with clearly different labels, but with an identical stitching pattern. The trial court found that there was no evidence of actual confusion by purchasers, but that non-purchasers seeing the jeans "worn by a passer-by" would likely be confused. The Second Circuit held that this post-sale confusion constituted trademark

licensed; here it is whether they believe Nike is actually selling the T-shirts. The latter is closer to the core of consumer confusion, and the law presumably should respond to such a consumer belief.

116799 F.2d 867 (2d Cir. 1986). 
infringement: "The confusion the Act seeks to prevent in this context is that a consumer seeing the familiar stitching pattern will associate the jeans with [Levis] and that association will influence his buying decisions." ${ }^{117}$ The doctrine of post-sale confusion can take care of a significant number of counterfeiting cases without the need for a merchandising right. It is important not to assume that any use of a logo will inevitably confuse viewers after the sale, however. Courts sometimes reject logo counterfeiting claims where it does not appear likely that consumers will be confused. ${ }^{118}$

A third concern might exist even in the absence of post-sale confusion. For certain types of goods - called Veblen goods - the value of the good to a consumers is a function of scarcity and corresponding exclusivity or "snob appeal." Veblen goods therefore exhibit a sort of anti-network effect; acquisition of the good by new consumers actually reduces the value of the good to existing owners. ${ }^{119}$ Judge Kozinski suggests that for Veblen goods, exclusive control over merchandising may help preserve the image consumers want to associate with the goods. Even if neither the buyer nor anyone else who sees them believes that counterfeit Rolex watches are real, if they proliferate it may destroy consumer expectations about what it means to wear a Rolex. ${ }^{120}$ There may therefore be a loss of social surplus resulting from competition, because counterfeiting a

117 Id. at _. See also Car-Freshner Corp. v. Big Lots Stores Inc., 314 F. Supp. 2d 145 (N.D.N.Y. 2004).

118 See, e.g., Louis Vuitton Malletier v. Burlington Coat Factory, 71 U.S.P.Q.2d 1507 (S.D.N.Y. 2004) (rejecting claim of counterfeiting of knock-off handbags where differences made consumers unlikely to be confused).

119 See Stan Liebowitz \& Stephen Margolis, Seventeen Famous Economists Weigh in on Copyright: The Roles of Theory, Empirics, and Network Effects [draft at 6] (working paper December 2003) (modeling Veblen goods as a form of negative network effect).

120 See Kozinski, supra note _, at 969-70; accord Richard S. Higgins \& Paul H. Rubin, Counterfeit Goods, 29 J.L. \& ECON. 211, 214 (1986). 
Veblen good harms consumers of the true Veblen good in a way that counterfeiting a non-Veblen good does not.

We are not fully persuaded that this economic concern justifies the creation of a merchandising right for Veblen goods. By definition, the counterfeit goods in this category are ones that people don't associate with Rolex; otherwise, they will be covered under the regular or post-sale confusion rationales discussed above. If they don't associate the counterfeit goods with Rolex, it is not clear that existing owners of Veblen goods will be harmed. And consumers of the distinguishable knockoff will clearly benefit. ${ }^{121}$ Alternatively, even if this is a valid utilitarian rationale for a merchandising right, it does not extend beyond Veblen goods to normal goods.

A final concern, and what may really be animating much of the push for merchandising protection, is an interest in protecting the product itself. It is no accident that Rolex is the most often used example of counterfeiting, and that many of the other examples involve the exact duplication of products and not just brand names. People's sympathies are naturally aroused by the fact that the defendant is copying the plaintiff's product almost exactly. There seems something wrong with the defendant copying the plaintiff's design, particularly if the economic effect may be for consumers to substitute the cheap knock-off for the more expensive genuine product.

We think this final instinct, while understandable, is misplaced. The Lanham Act

121 Cf. Shelly Branch, Style \& Substance: Hermes's Jelly Ache, Wall St. J., Apr. 9, 2004, at B1 (describing demand for knockoffs of Hermes "jelly bags," and suggesting that Hermes may have squeezed up prices of the knockoffs by aggressively pursuing sellers). 
is not a design protection statute. U.S. law gives limited protection for the actual design of a product through design patent law, copyright law, and sui generis protection for vessel hull designs. ${ }^{122}$ European law gives somewhat more protection. ${ }^{123}$ Each of those laws is animated by a desire to encourage the creation of new designs. Further, each law is limited in duration, and the designs so protected eventually enter the public domain. Trademark law, by contrast, is ill-suited to serve as a design protection statute. Its purposes are consumer protection and information disclosure, not encouraging creativity. Its protection lasts forever, and does not initially vest with the first creator, but rather the first to use the design to brand its goods. One of the real risks of the merchandising theory is precisely that it will subvert the proper goals of trademark law and leave in its place an ill-tailored, overreaching form of judicial design legislation.

\section{E. Can Dilution Save the Merchandising Right?}

Trademark law has recently expanded beyond its traditional scope of likelihood of confusion to protect the owners of certain famous marks against "dilution." ${ }^{\text {"124 }}$ Could dilution provide a back-door way of obtaining merchandising rights for famous trademarks? We think it is unlikely, for two reasons.

First, the theoretical basis for a dilution claim does not cover merchandising.

122 See, e.g., 35 U.S.C. §§ 171-173 (design patent law); 17 U.S.C. § 101 (defining "useful articles" subject to copyright protection); id. §§1301-1332 (Vessel Hull Protection Act).

123 European Design Protection Directive, 98/71/EC (October 1998).

12415 U.S.C. § 1125(c). 
Some have criticized dilution law for treating trademarks as property. ${ }^{125}$ But, properly understood, dilution is targeted at reducing consumer search costs just as traditional trademark law is. Dilution takes two forms: blurring the distinctive significance of a mark by associating it with lots of different products, and tarnishing the image of the mark by associating it with unwholesome products. Both blurring and tarnishment can make it somewhat more difficult for consumers to associate a famous mark with its owner.

Merchandising uses do not blur the distinctive significance of a mark in the mind of consumers. Rather, they reinforce it. The University of Texas might suffer blurring of its brand if the color orange and the image of a longhorn with the intertwined letters "UT" were used as a trademark to sell unrelated goods. But if the logo appears on Tshirts worn by UT fans, that use strengthens the connection in the minds of the public between the logo and the University. Merchandising uses are unlikely to create blurring problems.

In certain cases trademark dilution law will protect the owners of famous marks against the use of their mark in a way that will tarnish the trademark. ${ }^{126}$ But tarnishment requires proof that the defendant used the mark to brand goods, not just that they used the

125 See, e.g., Kenneth L. Port, Trademark Monopolies in the Blue Nowhere, 28 Wm. Mitchell L. Rev. 1091 (2002); Kenneth L. Port, The "Unnatural" Expansion of Trademark Rights: Is a Federal Dilution Statute Necessary?, 85 Trademark Rptr. 525 (1995).

126 See, e.g., Coca-Cola v. Gemini Rising, Inc., 346 F.Supp. 1183 (E.D.N.Y. 1972) (enjoining use of a poster using the Coca-Cola colors and font that read "Enjoy Cocaine"). 
mark as the subject of a T-shirt. ${ }^{127}$ For example, if a defendant sells Toyota brand pornography, those who encounter the use may think less highly of the Toyota brand name because they subconsciously associate it with pornography, even if they understand that the car company did not itself sponsor the materials. By contrast, an irate consumer wearing a T-shirt that says "Toyota sucks" or shows a cartoon character urinating on the Ford logo isn’t tarnishing the brand in the sense the law cares about. These protest uses don't interfere with consumers' association between the logo and the company through some subconscious pollution. If anything, they strengthen the mental connection between trademark holder and mark, albeit in a way the company might not like. The use of logos on merchandise isn't actionable as tarnishment, therefore, as long as the point of the logo is to refer to the trademark owner and not to brand an unrelated product. To be sure, courts applying the tarnishment doctrine have sometimes used it to target criticism or derogatory speech about the trademark owner, a result that finds little justification in the search cost rationale. ${ }^{128}$ Those courts are clearly mistaken in their understanding of the doctrine, however, and most courts properly distinguish the two. ${ }^{129}$

Second, even if dilution theory were somehow stretched to cover merchandising, as a practical matter the federal dilution statute seems unlikely to provide the kind of protection against the use of logos that trademark owners desire. First, the Supreme

127 See L.L. Bean, Inc. v. Drake Publishers, 811 F.2d 26 (1 ${ }^{\text {st }}$ Cir. 1987) (defining tarnishment); 4 J. Thomas McCarthy, McCarthy on Trademarks and Unfair Competition $\S \ldots$.

128 See, e.g., Deere \& Co. v. MTD Prods., 41 F.3d 39 (2d Cir. 1994).

129 See, e.g., Mattel, Inc. v. Walking Mountain Productions, 353 F.3d $792\left(9^{\text {th }}\right.$ Cir. 2003); Mastercard Int'l v. Nader 2000 Primary Committee, 70 U.S.P.Q.2d 1046 (S.D.N.Y. 2004). 
Court in 2003 construed the statute as requiring trademark owners to prove actual dilution of the significance of their mark, rather than merely a likelihood of dilution, at least where the marks were not identical. ${ }^{130}$ As a practical matter demonstrating actual dilution has proven extremely difficult, ${ }^{131}$ rendering the federal dilution statute of little practical value to trademark owners. Further, even if the likelihood of dilution standard were reinstated, ${ }^{132}$ the dilution law applies only to "commercial use in commerce" of the mark. $^{133}$ This test requires use of the mark as a brand in proposing a commercial transaction, ${ }^{134}$ something that printing a logo on a T-shirt simply doesn't do. For all of these reasons, it seems unlikely that trademark owners will be able to use federal dilution law to justify a merchandising right. ${ }^{135}$

\footnotetext{
130 Moseley v. V Secret Catalogue, 537 U.S. 418 (2003). The Court twice distinguished the case of identical marks, but never held that they were subject to the likelihood of dilution standard.

131 For examples of cases rejecting dilution claims after Moseley, see, e.g., Nitro Leisure Prods. v. Acushnet Co., 341 F.3d 1356 (Fed. Cir. 2003); Kellogg Co. v. Toucan Golf, Inc., 337 F.3d 616 (6 ${ }^{\text {th }}$ Cir. 2003); Starbucks Corp. v. Lundburg, 2004 WL 1784753 (D. Or. Aug. 10, 2004); Mastercard Int'l v. Nader 2000 Primary Committee, 70 U.S.P.Q.2d 1046 (S.D.N.Y. 2004); HBP, Inc. v. American Marine Holdings, 290 F. Supp. 2d 1320 (M.D. Fla. 2003). The courts in General Motors Corp. v. Autovation Technologies, Inc., 317 F. Supp. 2d 756, 764 (E.D. Mich. 2004) and 7-Eleven Co. v. McEvoy, 300 F. Supp. 2d 352 (D. Md. 2004) did find actual dilution under the Moseley standard in cases where the trademarks were identical.

132 The International Trademark Association has proposed legislation to do just that.

13315 U.S.C. $\S 1125(\mathrm{c})$.

134 See H.R. Rep. 104-374, $104^{\text {th }}$ Cong., $1^{\text {st }}$ Sess. (1995) (adopting existing constitutional standards of “commercial speech”).

135 Moseley does not apply to state dilution statutes, and some of them might be interpreted more broadly than the federal act. However, these statutes are still targeted at blurring and tarnishment, neither of which are properly at issue in the merchandising cases.
} 


\section{Merchandising Rights and the Supreme Court}

While the merchandising right might seem to be a fait accompli despite its dubious legal basis, recent developments suggest that the time may be right to reopen the debate. $^{136}$ In particular, the Supreme Court's trademark jurisprudence over the past decade has shown a return to core trademark values, with consumer expectations a central focus and the value of competition paramount. At the very least, these cases validate the trend toward requiring confusion in merchandising cases, and away from the more generalized right enunciated in Boston Hockey and its progeny. But they may go much further. Beyond reaffirming an approach to trademark law heavily rooted in informational harm and consumer expectations, these opinions manifest a deep-rooted concern for the inherent value of competition in product markets. If competitive markets are the ultimate goal, the solution, even in merchandising cases raising risks of sponsorship-based confusion, may lie in something short of an absolute injunction against use of the mark. ${ }^{137}$

\section{A. Consumer Perceptions and Confusion as to Source}

Beginning with our more modest contention, it seems clear that the current Supreme Court would reject a merchandising claim that did not turn on confusion as to source or sponsorship. Over the past decade, the Court has insisted with increasing vigor

136 See Withers, supra note _

The debate over the merchandising right has raged since the mid-1970s, and many courts and commentators have contended that the right ignores both the confusion requirement and the need for competitors to have access to features that consumers find important to the appeal of a product. See, e.g., [string cites].

137 See generally Bone, supra note _ (advocating disclaimer as the exclusive remedy in merchandising cases generally). 
that trademark rights and trademark infringement both depend upon consumer expectations and perceptions, rather than some abstract equitable code of conduct. Unless consumers perceive a mark as a brand, it does not merit protection; and unless consumers perceive a defendant's use of the mark as an indication of product source or sponsorship, the use does not infringe. These principles flow inevitably from trademark law's emphasis on informational clarity and competition, and argue against a broad merchandising right for trademark holders.

As to the first point, the Supreme Court has consistently held (and the Lanham Act requires) $)^{138}$ that trademark status depends on proof that consumers are likely to perceive the mark as a brand. Absent a "consumer predisposition to equate the feature with the source," 139 the mark is not serving as a trademark, and its use by others cannot infringe. From a search costs perspective, this makes perfect sense: unless a feature serves as a brand, its use by competitors will not confuse consumers as to the source or sponsorship of the competitors' products, and the clarity of marketplace information will be unaffected. Consumers, meanwhile, will benefit from competition among sellers of the feature. And while the Court has held that some word marks and trade dress by their nature serve to indicate source, ${ }^{140}$ others - such as product configuration ${ }^{141}$ and color $^{142}-$

138 See 15 U.S.C. $§ 1127$ (defining trademark as a symbol that "indicates the source" of a product, even if the source is unknown).

${ }^{139}$ Wal-Mart Stores, Inc. v. Samara Bros., Inc., 529 U.S. 205, 213 (2000); see also id. ("Consumers are aware of the reality that, almost invariably, even the most unusual of product designs - such as a cocktail shaker shaped like a penguin - is intended not to identify the source, but to render the product itself more useful or appealing.”).

${ }^{140}$ In Two Pesos, Inc. v. Taco Cabana, Inc., 505 U.S. 763 (1992), the Court held that inherently distinctive trade dress could qualify for protection without a showing of secondary meaning. To be "inherently distinctive," however, the mark's "intrinsic nature" must "serv[e] to identify a particular source of a product" - i.e., consumers must 
are presumed to serve an aesthetic rather than source-identifying function until secondary meaning is established. ${ }^{143}$ The Court's focus on consumer perceptions follows from trademark law's competition-based rationale: absent some indication that a competitor's use of a product feature will confuse consumers and therefore increase their search costs, competition in that feature will best serve the interests of the public. ${ }^{144}$

This consumer-perceptions-based eligibility standard has both direct and indirect implications for merchandising claims. Doctrinally, it suggests that a trademark holder cannot establish distinct rights in the mark as a trademark for merchandise ${ }^{145}$ without

perceive it as a brand, albeit one with which they may not yet be familiar. 505 U.S. at 768; see also id. at 769 (citing Restatement, Third, of Unfair Competition § 13 \& comment (a)); Restatement, Third, of Unfair Competition § 13(a) (a mark is "inherently distinctive" if, "because of the nature of the designation and the context in which it is used, prospective purchasers are likely to perceive it as a designation that ... identifies goods or services produced or sponsored by a particular person, whether known or anonymous") (emphasis added); id. comment (b) (defining inherently distinctive marks as designations that "by their nature are likely to be perceived by prospective purchasers as symbols of identification that indicate an association with a particular source").

${ }^{141}$ See Wal-Mart Stores, Inc. v. Samara Bros., Inc., 529 U.S. 205 (2000).

${ }^{142}$ Qualitex Co. v. Jacobson Products, Inc., 514 U.S. 159 (1995). In Qualitex, the Court held that a product's color could serve as a trademark, but only "where that color has attained 'secondary meaning' and therefore identifies and distinguishes a particular brand (and thus indicates its 'source')". 514 U.S. at 163. Because color "does not immediately ... signal a brand or a product 'source,"” id. at 162-63, its protection depends upon evidence of actual consumer perceptions.

${ }^{143}$ A mark has acquired secondary meaning when, "as a result of its use, prospective purchasers have come to perceive it as a designation" of source or sponsorship of the goods on which it appears. Rest. (Third) of Unfair Comp. § 13(b).

144 See Wal-Mart Stores, Inc. v. Samara Bros., Inc., 529 U.S. 205, 213 (2000) ("Consumers should not be deprived of the benefits of competition with regard to the utilitarian and esthetic purposes that product design ordinarily serves by a rule of law that facilitates plausible threats of suit against new entrants based upon alleged inherent distinctiveness.”).

145 Trademark holders have asserted two distinct types of merchandising claims. First, some have claimed that they have established rights over a mark as used on merchandise, 
proving that consumers are likely to view it as a source indicator, ${ }^{146}$ rather than as an inherently pleasing feature, when they see it incorporated into licensed products. ${ }^{147}$ If this standard turns - as it should - on evidence rather than supposition, it will rarely be met in a trademark merchandising case. ${ }^{148}$ More generally, the Supreme Court's

either through common law usage (or licensing) or through registration, and that the defendant's use confuses consumers based on that merchandise-based brand. E.g., National Football League Properties, Inc. v. Wichita Falls Sportswear, Inc., 532 F. Supp. 651, 659 (W.D. Wash. 1982) (imposing requirement of secondary meaning as to sponsorship, which "requires a showing that the public believes that the product bearing the mark is sponsored or endorsed by plaintiff," and finding requirement satisfied based on survey evidence). This approach gives trademark holders a considerable advantage in establishing likelihood of confusion, which weighs heavily the relatedness of goods offered by the two parties. See, e.g., Boston Athletic Ass'n v. Sullivan, 867 F.2d 22, 30 $\left(1^{\text {st }}\right.$ Cir. 1989) (finding confusion likely based partly on the fact that the BAA and defendant "offer virtually the same goods: shirts and other wearing apparel”).

Alternatively - and more commonly - merchandising claims are based on the trademark holder's rights in its primary market for sports, education, entertainment, and the like. The trademark holder in such a case must establish that the defendant's use confuses consumers despite the differences in products offered under the mark. See, e.g., Board of Gov. of Univ. of N. Carol. v. Helpingstine, 714 F. Supp. 167, 172-73 (M.D. N.C. 1989) (agreeing "with Professor McCarthy that similarity or even identity of marks is not sufficient to establish confusion where non-competitive goods are involved"); University of Pittsburgh v. Champion Prods., Inc., 566 F. Supp. 711, 719-20 (W.D. Pa. 1983).

${ }^{146}$ By “source indicator,” we mean an indication of source or sponsorship.

147 See University of Pittsburgh v. Champion Prods., Inc., 566 F. Supp. 711, 717 (W.D. Pa. 1983) ("Although there may be some evidence in the record which would tend to suggest that the Pitt insignia have taken on a secondary meaning for the provision of educational and athletic services, there is simply no evidence that the Pitt insignia ever have had any secondary meaning for soft goods.”); compare National Football League Properties, Inc. v. Wichita Falls Sportswear, Inc., 532 F. Supp. 651, 659 (W.D. Wash. 1982) (imposing requirement of secondary meaning as to sponsorship, which "requires a showing that the public believes that the product bearing the mark is sponsored or endorsed by plaintiff,” and finding requirement satisfied based on survey evidence).

148 Indeed, it is rarely even asserted. See Board of Gov. of Univ. of N. Carol. v. Helpingstine, 714 F. Supp. 167, 172 \& n.2 (M.D. N.C. 1989) (treating merchandising case as one involving unrelated goods, despite University's sale of merchandise in its bookstore, because sale of such merchandise "is not the primary business of the University”); University of Pittsburgh v. Champion Prods., Inc., 566 F. Supp. 711, 717 (W.D. Pa. 1983); cf. University of Georgia Athletic Ass’n v. Laite, 756 F.2d 1535, 1547 
faithfulness to a consumer-based approach to trademark law reaffirms the traditional notion of trademark law as a facilitator of fair competition, rather than a property-based regime, and implicitly rejects the unjust enrichment impulse reflected in Boston Hockey and its progeny. ${ }^{149}$

Admittedly, the eligibility cases do not directly address the core question in many merchandising cases: whether infringement requires real likelihood of confusion as to product source, or whether it's enough to show that the public recognizes the trademark as emanating from the complaining party. But the Court has recently given clear guidance on this question in two other cases. First, in Moseley v. V Secret Catalogue, the Court rejected the idea that mere mental association between the plaintiff's trademark and the defendant's product could suffice to prove dilution of that trademark. ${ }^{150}$ And if mental association is not enough to satisfy the dilution standard, it certainly won't be enough to show likelihood of confusion.

(11 ${ }^{\text {th }}$ Cir. 1985) (adopting Boston Hockey approach, and finding lack of product proximity "less significant in the instant case," where "the confusion stems not from the defendant's unfair competition with the plaintiff's products, but from the defendant's misuse of the plaintiff's reputation and goodwill as embodied in the plaintiff's mark"). But see Boston Athletic Ass'n v. Sullivan, 867 F.2d 22, 28-30 ( $1^{\text {st }}$ Cir. 1989) (asserting without further discussion that "apparel is related to the service provided by the BAA, the race, and BAA is entitled to enjoin use of its mark on such items," and going on to analyze likelihood of confusion under a related-goods approach).

149 See generally Traffix Devices, Inc. v. Marketing Displays, Inc., 532 U.S. 23, 28 (2001) ("protection for trade dress exists to promote competition") (emphasis added); Qualitex Co. v. Jacobson Products, Inc., 514 U.S. 159, 164 (1995) (trademark law “seeks to promote competition by protecting a firm's reputation"). Compare University Book Store v. Board of Regents of University of Wisconsin, 1994 WL 747886, at *8 (TTAB 1984) (describing as "antiquated" the "view of trademarks as harmful monopolies which must be rigorously confined within traditional bounds").

Moseley v. V Secret Catalogue, 537 U.S. 418 (2003). 
Second, the Court's decision in Dastar Corp. v. Twentieth Century Fox Film Corp., ${ }^{151}$ directly refutes the idea that infringement can occur without confusion as to the source or sponsorship of the goods, and discredits the notion that any other form of mental association counts in evaluating infringement. Dastar involved a "reverse passing-off" claim based on the sale of videotapes containing a movie created by the plaintiff, but sold under the defendant's name. The plaintiff contended that defendant deceived the public into thinking that it, rather than plaintiff, had made the movie, and that the sale of the movie under defendant's name constituted a false designation of origin under the Lanham Act. ${ }^{152}$ The Court rejected this theory, reasoning that "origin ... of goods" under the Lanham Act refers to the origin of the physical product sold in the marketplace, rather than any ideas or communications included inside:

We think the most natural understanding of the 'origin' of 'goods' - the source of wares - is the producer of the tangible product sold in the marketplace, in this case the physical ... video sold by Dastar. The concept might be stretched ... to include not only the actual producer, but also the trademark owner who commissioned or assumed responsibility for ('stood behind') production of the physical product. But as used in the Lanham Act, the phrase 'origin of goods' is in our view incapable of connoting the person or entity that originated the ideas or communications that 'goods' embody or contain. ${ }^{153}$

While most merchandising claims involve allegations of confusion as to product

${ }^{151} 539$ U.S. 23.

${ }^{152}$ Id. at 27; see 17 U.S.C. § 1125(a)(1) (providing a cause of action against a "false designation of origin, false or misleading description of fact, or false or misleading representation of fact, which ... is likely to cause confusion ... as to the origin ... of his or her goods"). The Dastar case was complicated by the fact that copyright in the movie had expired, leaving the movie in the public domain. Id. at 26. The Court did not limit its analysis to cases involving expired copyrights, however, and subsequent decisions have not read it that narrowly. See, e.g., Williams v. UMG Recordings, Inc., $281 \mathrm{~F}$. Supp. 2d 1177, 1185 (C.D. Cal. 2003).

${ }^{153}$ Dastar, 539 U.S. at 31-32. 
sponsorship, rather than origin, the Dastar reasoning has no less force in the sponsorship context. To succeed in a sponsorship claim after Dastar, a trademark holder must establish that defendant's use of its mark will confuse consumers into believing it sponsored the good sold by defendant. In merchandising cases, this means that the trademark holder must establish that consumers are likely to believe that it makes or stands behind the t-shirt, cap, or other merchandise at issue in the case. Boston Hockey's notion that infringement can turn on confusion as to source of the mark - i.e., of "the ideas or communications" embodied in the product ${ }^{154}$ - runs directly counter to this ruling. ${ }^{155}$

Indeed, Dastar seems particularly applicable in the merchandising context. When fans buy Harvard shirts, or Chicago Cubs hats, or Rolling Stones tattoos, or Winnie-thePooh cakes from the local bakery, they are doing so not because they believe that Harvard or the other trademark holders made or sponsored the good, but because the trademark in this context serves an important communicative function for them. ${ }^{156}$ Just

${ }^{154} I d$.

155 See Boston Hockey, 510 F.2d 1004, 1011 ("The certain knowledge of the buyer that the source and origin of the trademark symbols were in plaintiffs satisfies the requirement of the act.”).

156 This is arguably truer in merchandising cases than in cases involving books, movies, and other creative works like the film in Dastar itself, in which consumers are arguably interested "not merely, if at all, in the identity of the producer of the physical tome (the publisher), but also, and indeed primarily, in the identity of the creator of the story it conveys." 539 U.S. at 32. While acknowledging this tension, the Supreme Court in Dastar found its approach critical to preserving the balance between trademark and copyright law. See id. at 33. In any event, its reasoning clearly applies to products valued for something other than their intellectual content. See id. The basic premise that consumer expectations need to be taken into account before deciding that the use of the mark misleads the public as to source or sponsorship - translates readily into the merchandising context. 
as in Dastar, the communication may come in the form of material protected by copyright, ${ }^{157}$ or it may not; but the use of the trademark is unlikely to tell consumers anything about the source of the goods bearing the mark, as opposed to the source of the trademark or logo itself. And absent such an association, trademark law should have nothing to say about the use of the mark. Lower courts interpreting Dastar have applied it rigorously in such contexts, rejecting claims for passing off where the origin of the goods is not in question, even if the plaintiff claims the underlying work originated with $\operatorname{him}^{158}$

Dastar reiterates the principle that has driven Supreme Court trademark jurisprudence in recent years: trademark law aims primarily to reflect consumer perceptions about brands and to validate their expectations as to the source of goods in the marketplace. Together with Moseley, it makes it clear that the Court would, at the very least, make a showing of confusion a necessary condition to any merchandising claim. ${ }^{159}$ Read most broadly, they could require proof that it matters to consumers

157 Winnie the Pooh, for example, still enjoys copyright protection, and the use of its image may raise copyright concerns.

158 See, e.g., Zyla v. Wadsworth, 360 F.3d 243, 251-52 (1 ${ }^{\text {st }}$ Cir. 2004); Bob Creeden \& Assoc. v. Infosoft Inc., _ F. Supp. 2d _, 2004 WL 830456 (N.D. Ill. April 14, 2004); Bretford Mfg., Inc. v. Smith System Mfg Co., 286 F. Supp. 2d 969, 971-72 (N.D. Ill. 2003) ("There was no misrepresentation as to the 'origin' of the tables, ... because there was no misrepresentation, express or implied, as to the source of the components of the tables.”).

159 See Williams v. UMG Recordings, Inc., 281 F. Supp. 2d 1177 (C.D. Cal. 2003) (finding no infringement when defendants rightly identified themselves as "the 'origin"” of film "insofar as that term is used to define the manufacturer or producer of the physical goods that were made available to the public," even though the film contained plaintiffs' copyrighted material). 
whether the trademark holder has officially sponsored merchandise bearing its mark. ${ }^{160}$ As the Supreme Court stated in Dastar, "The words of the Lanham Act should not be stretched to cover matters that are typically of no consequence to purchasers.”161

\section{B. Functionality and the Costs of Trademark Rights}

In addition to firming up the connection between trademark infringement and marketplace clarity, the Court's recent jurisprudence has shown a renewed emphasis on the costs of trademark protection, and has suggested that these costs may sometimes justify a refusal to grant relief even when the plaintiff has produced a risk of confusion. In particular, the Court has underscored the importance of trademark's functionality doctrine in maintaining competitive markets. As discussed above, the functionality doctrine prevents a trademark holder from claiming rights to a feature if it is " "essential to the use or purpose of the article or affects the cost or quality of the article,' that is, if exclusive use of the feature would put competitors at a significant non-reputation-related disadvantage."162 And while the contours of the functionality doctrine have proven challenging to fix, its basic rationale is simple: for a competitive marketplace to function, competitors must have access to product features that consumers want for their inherent

${ }^{160}$ See supra notes ____ and accompanying text (discussing trademark law as norms reflector or creator); see also University of North Carolina v. Halpingstine, 714 F. Supp. 167, 173 ("In essence, the court is skeptical that those individuals who purchase unlicensed tee-shirts bearing UNC-CH's marks care one way or the other whether the University sponsors or endorses such products or whether the products are officially licensed.”).

${ }^{161}$ Dastar, 539 U.S. at 33.

162 Qualitex Co. v. Jacobson Products, Inc., 514 U.S. 159, 165 (1995) (quoting Inwood Labs., Inc. v. Ives Labs., Inc., 456 U.S. 844, 850 \& n.10 (1982)). 
value, not because they indicate source. ${ }^{163}$

The functionality doctrine appears perfectly suited for the merchandising context. In many - perhaps most - merchandising sales, competitors cannot satisfy consumers’ demand by substituting an alternative product feature for the trademark; because the trademark effectively is the product, consumers will settle for nothing less than it. ${ }^{164}$ The trademark therefore undeniably "affects the cost or quality of the article" and gives an insurmountable competitive advantage to the trademark holder. Applying this reasoning, a number of merchandising cases have used functionality as one basis for denying the trademark holder’s claim. ${ }^{165}$

The standard for functionality has long been a matter of dispute, however, particularly as applied to ornamentation rather than actual performance characteristics so-called "aesthetic functionality." Under some articulations, the standard gives trademark holders some traction in arguing against its application. The Supreme Court

\footnotetext{
163 See id. at 170 .
}

164 A Chicago Cubs fan seeking a baseball cap will not be satisfied with a hat with any other feature, regardless of competitors' efforts to devise aesthetically attractive designs. Compare W.T. Rogers Co., Inc. v. Keene, 778 F.2d 334, 340 ( $7^{\text {th }}$ Cir. 1985) (asserting that "it would be unreasonable to deny trademark protection to a manufacturer who had the good fortune to have created a trade name, symbol, or design that became valued by the consuming public for its intrinsic pleasingness as well as for the information it conveyed about who had made the product," and charging competitors with responsibility to create alternative attractive products).

${ }^{165}$ E.g., International Order of Job’s Daughers v. Lindenburg \& Co., 633 F.2d $912\left(9^{\text {th }}\right.$ Cir. 1980) (" $[I] n$ the context of this case, the name and emblem are functional aesthetic components of the jewelry, in that they are being merchandised on the basis of their intrinsic value, not as a designation of origin or sponsorship.”); University of Pittsburgh v. Champion Prods., Inc., 566 F. Supp. 711, 720-21 (W.D. Pa. 1983) ("Because the Pitt insignia on soft goods serve a functional purpose and largely define a sub market of some size, granting Pitt the relief it seeks would give Pitt a perpetual monopoly over that sub market, precluding any competition in the Pitt insignia soft goods market.”). 
has sometimes described functional features as those whose competitive advantage derives from their inherent qualities and not because of the reputation of the trademark holder. ${ }^{166}$ Seizing on this language, some courts have rejected the functionality doctrine ${ }^{167}$ in merchandising cases, reasoning that because the very appeal of trademark merchandise lies in the reputation reflected in the trademark, the marks by definition cannot be declared functional. ${ }^{168}$

The problem with this rationale lies in its overly broad understanding of the type of "reputation-related advantage" that can make a feature non-functional. It seems clear that the Court's distinction between functional and non-functional features aims to differentiate between features that confer a competitive advantage because of their inherent nature, on the one hand, and those that do so because they indicate something about the source of the product, on the other. ${ }^{169}$ The type of "reputational advantage" that a non-functional mark confers, in other words, is in conveying valuable information

166 See Qualitex, 514 U.S. at 165 (referring to "non-reputation-related advantage" conferred by functional features); id. at 169 ("The functionality doctrine thus protects competitors against a disadvantage (unrelated to recognition or reputation) that trademark protection might otherwise impose, namely, their inability reasonably to replicate non-reputation-related product features.”) (emphasis added).

${ }^{167}$ Technically, the plaintiff bears the burden of establishing the non-functionality of its trademark, but given the unusual nature of the functionality issue in merchandising cases - the mark claimed to be functional is admittedly a protected trademark - defendant typically raise the issue in these cases. After it does so, however, plaintiff bears the burden of establishing non-functionality.

168 See, e.g., Warner Bros. v. Gay Toys, Inc., 724 F.2d 327, 330 (2d Cir. 1983) (describing functionality argument as "paradoxical ..., since it is precisely the fact that the symbols provide identification that make them 'functional' in the sense urged by Gay Toys, while Warner's exclusive right to use its own identifying symbols is exactly what it seeks to protect.").

169 See Qualitex, 514 U.S. at 165 (suggesting a feature is functional if it "plays an important role in making a product more desirable”). 
to consumers about the reputation or qualities of the trademark holder as source or sponsor of the product. The Restatement of Unfair Competition establishes this quite clearly. ${ }^{170}$ An alternative reading would conflict with the lesson in Dastar that, when trademark law talks about source or origin, it refers to the source or origin of the goods at issue in a case, and not of their ingredients or other attributes. It would also conflict with the Supreme Court's most recent formulation of the functionality doctrine in TrafFix, where the Court clearly contemplated a co-equal role for traditional and aesthetic functionality. $^{171}$

Nonetheless, there may be merchandising cases in which the trademark serves as both source-identifier and as a critical feature of the product, so that it confers both reputation-related and non-reputation-related advantage to those who use it. ${ }^{172}$ In these cases, the ultimate competitive effect of allowing trademark rights may be difficult to gauge: on the one hand, the reputational concerns may drive some purchasers mistakenly to assume an affiliation between the parties and thereby increase search costs; but on the other, the absence of competition may force consumers to pay a premium for the good, even when many of them don't particularly care whether the product was officially licensed.

If the Supreme Court's recent analysis of functionality is any guidance, the

170 Restatement (Third) of Unfair Competition $\S 17$ (1995) (“A design is functional” if it "affords benefits in the manufacturing, marketing, or use of the goods or services with which the design is used, apart from any benefits attributable to the design's significance as an indication of source, that are important to effective competition by others and that are not practically available through the use of alternative designs.”) (emphasis added).

171 Traffix Devices, Inc. v. Marketing Displays, Inc., 532 U.S. 23, 34-35 (2001).

${ }^{172}$ Wichita Falls, for example, may be one such case. 
solution in these cases should lie short of enjoining the mark. The Court has stated unequivocally that functional features may not be protected under trademark law, even if they have also come to indicate source. ${ }^{173}$ For features that actually help to make the product work better, this is true without regard to their impact on competition. ${ }^{174}$ But even for features that are "aesthetically functional," the Court has suggested that competitors must have access to the feature if the alternative would leave competitors at a disadvantage beyond that attributable to reputation. ${ }^{175}$

None of this suggests an open season on the use of trademarks on merchandise. As discussed above, there may be occasions in which such use will create confusion that could affect the trademark holder's reputation and cannot be dispelled with a disclaimer. ${ }^{176}$ Even in other cases involving sponsorship rather than source confusion, the particular usage at issue may imply the kind of official sponsorship that justifies judicial relief. Claims of official sponsorship are clearly not functional; the advantage they confer comes exclusively through reputational concerns rather than aesthetic or communicative ones. But in other instances, the functionality doctrine suggests that the public should have the benefit of competition in the sale of products that they desire, including products whose primary aesthetic feature constitutes a trademark. If - and only if - such competition risks creating misperceptions as to whether the trademark holder

173 TrafFix, 532 U.S. at 33 ("Functionality having been established, whether MDI’s dual spring design has acquired secondary meaning need not be considered.”).

${ }^{174}$ Id.

175 See, e.g., Qualitex, 514 U.S. at 169-70; TrafFix, 532 U.S. at 33 (aesthetic functionality turns on whether the feature confers a substantial advantage unrelated to reputation).

176 Post-sale confusion is an example, as is the use of logos on items related to the trademark holder's primary market. See supra notes and accompanying text. 
endorsed the product, the solution lies in correcting those misperceptions through disclaimers and corrective advertising, and not through enjoining use of the mark.

The Supreme Court's recent zeal for competition in trademark cases thus lends both theoretical and doctrinal muscle to the cause against a merchandising right. At the very least, the Court's recent decisions discredit the notion that a merchandising right can exist without any showing of confusion or other search-cost-related harm. But they may go further: the Court's repeated emphasis on the importance of competition and consumer interests suggests that when a trademark is integral to the appeal of a good or class of goods, competitors should be allowed to sell it, as long as they make their unofficial status clear.

\section{Conclusion}

While trademark owners, competitors, and perhaps even consumers act as though the merchandising theory is a fait accompli, where the courts are concerned it is ultimately a rather fragile theory. Judicial adoption of the theory has never been universal or even widespread. And the Supreme Court seems to have a firm idea of what trademark law is about, a vision that leaves no room for a merchandising right. It seems likely, therefore, that courts considering merchandising claims in the future will not be inclined to uphold them absent special circumstances.

We don't believe this should be cause for alarm. The merchandising theory has not been persuasive to courts in large measure because its justifications lack persuasive 
force. The arguments normally advanced for a merchandising right are circular and ultimately rather empty. Most of the good a merchandising right might do can be accomplished more directly using existing trademark doctrines such as post-sale confusion. Thus, we would eliminate the presumption of a merchandising right and put courts to the task of determining whether, under the circumstances, a particular use was in fact likely to confuse consumers as to source. If not, the competitor ought to have access to the mark as product without incurring the cost of labeling itself as an "unofficial” product. If confusion is likely, a disclaimer will ordinarily resolve it. We can imagine some circumstances in which the risk of post-sale confusion would justify an injunction, but they will be the rare cases. Most cases of consumer confusion can be solved without a merchandising right. And where there is no consumer confusion at all, the assertion of a pure right to control use of a mark for no other reason than because it is "mine" is at odds with trademark theory and good public policy. Consumers don’t need it, the statute doesn't support it, and we are well rid of it. 